\title{
Evaluating soil extraction methods for chemical characterization of ultramafic soils in Kinabalu Park (Malaysia)
}

Article

Accepted Version

Creative Commons: Attribution-Noncommercial-No Derivative Works 4.0

van der Ent, A., Nkrumah, P. N., Tibbett, M. and Echevarria, G. (2019) Evaluating soil extraction methods for chemical characterization of ultramafic soils in Kinabalu Park (Malaysia). Journal of Geochemical Exploration, 196. pp. 235246. ISSN 0375-6742 doi:

https://doi.org/10.1016/j.gexplo.2018.10.004 Available at https://centaur.reading.ac.uk/80181/

It is advisable to refer to the publisher's version if you intend to cite from the work. See Guidance on citing.

To link to this article DOI: http://dx.doi.org/10.1016/j.gexplo.2018.10.004

Publisher: Elsevier

All outputs in CentAUR are protected by Intellectual Property Rights law, including copyright law. Copyright and IPR is retained by the creators or other copyright holders. Terms and conditions for use of this material are defined in the End User Agreement. 


\section{CentAUR}

Central Archive at the University of Reading

Reading's research outputs online 


\section{Accepted Manuscript}

Evaluating soil extraction methods for chemical characterization of ultramafic soils in Kinabalu Park (Malaysia)

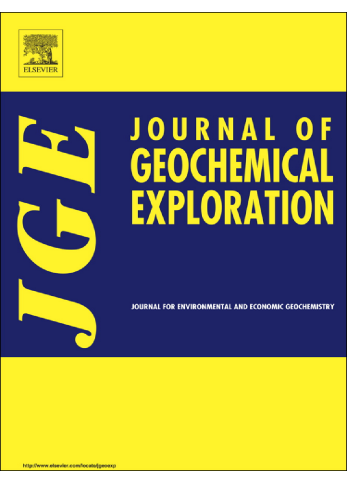

Antony van der Ent, Philip Nti Nkrumah, Mark Tibbett, Guillaume Echevarria

PII:

S0375-6742(18)30010-4

DOI: doi:10.1016/j.gexplo.2018.10.004

Reference: GEXPLO 6206

To appear in: Journal of Geochemical Exploration

Received date: 1 February 2018

Revised date: 14 August 2018

Accepted date: 15 October 2018

Please cite this article as: Antony van der Ent, Philip Nti Nkrumah, Mark Tibbett, Guillaume Echevarria , Evaluating soil extraction methods for chemical characterization of ultramafic soils in Kinabalu Park (Malaysia). Gexplo (2018), doi:10.1016/ j.gexplo.2018.10.004

This is a PDF file of an unedited manuscript that has been accepted for publication. As a service to our customers we are providing this early version of the manuscript. The manuscript will undergo copyediting, typesetting, and review of the resulting proof before it is published in its final form. Please note that during the production process errors may be discovered which could affect the content, and all legal disclaimers that apply to the journal pertain. 


\section{Evaluating soil extraction methods for chemical characterization of ultramafic soils in Kinabalu Park (Malaysia)}

Antony van der Ent ${ }^{1,2^{*}}$, Philip Nti Nkrumah ${ }^{1}$, Mark Tibbett ${ }^{3}$ and Guillaume Echevarria ${ }^{1,2}$

${ }^{1}$ Centre for Mined Land Rehabilitation, Sustainable Minerals Institute, The University of Queensland, Australia.

${ }^{2}$ Université de Lorraine, INRA, Laboratoire Sols et Environnement, 54000 Nancy, France.

${ }^{3}$ Centre for Agri-Environmental Research \& Soil Research Centre, School of Agriculture, Policy and Development, University of Reading, Reading, RG6 6AR, UK.

*Corresponding author: a.vanderent@uq.edu.au, Centre for Mined Land Rehabilitation, The University of Queensland, St Lucia QLD 4072, Australia. 


\section{ABSTRACT}

Soils derived from ultramafic bedrock are known for hosting distinct vegetation types as a consequence of atypical soil chemistries consisting of high trace elements concentrations $(\mathrm{Ni}$, $\mathrm{Cr}, \mathrm{Co}$ ) and exchangeable cation imbalances (high $\mathrm{Mg}: \mathrm{Ca}$ quotients). Ecological studies use a range of single-stage extraction methods for chemical characterization of such soils in order to be able to interpret plant response, and ultimately to explain plant community composition. Few studies to date have compared different soil extraction methods in relation to tropical ultramafic soils. This study compares eight commonly used extraction methods on a large number of ultramafic soil samples collected from Kinabalu Park (Malaysia). The tested methods were: for trace elements: $\mathrm{NH}_{4} \mathrm{AC}, \mathrm{DTPA}, \mathrm{CaCl}_{2}, \mathrm{Sr}\left(\mathrm{NO}_{3}\right)_{2}$ and Mehlich-3, for exchangeable cations: $\mathrm{NH}_{4} \mathrm{Ac}$ and silverthiorea, and for plant-available phosphorus: Mehlich3 and Olsen-P. These single-stage extraction methods were compared and evaluated for predictive power for chemically characterizing soils, interrelatedness and ecological application. The methods were also contrasted with a sequential extraction scheme. Finally, several operational parameters including molar ratio (0.01 and $\left.0.1 \mathrm{M} \mathrm{CaCl}_{2}, \operatorname{Sr}\left(\mathrm{NO}_{3}\right)_{2}\right)$ and pH buffering (DTPA-TEA) were also evaluated. The majority of single-stage extraction methods are highly inter-correlated and predictive power could be improved by including independent soil parameters ( $\mathrm{pH}, \mathrm{CEC}$, pseudo-total element concentration) in the multivariate regression equation. Ecological interpretation remains difficult because of lack of experimental studies in relation to plant uptake response and potential phytotoxicity effects on tropical native plants from ultramafic soils.

Keywords: carboxylic acid, DTPA, multivariate regression, single-stage extraction, sequential extraction scheme, strontium nitrate. 


\section{INTRODUCTION}

Ultramafic rocks are widespread on earth, particularly in tropical countries (Cuba, New Caledonia, Indonesia, Philippines and Malaysia). These rocks are parts of the upper mantle and consist largely of magnesium-iron-silicate minerals. Soils derived from such bedrock are relatively high in the trace elements nickel $(\mathrm{Ni})$, cobalt $(\mathrm{Co})$ and chromium $(\mathrm{Cr})$, but concomitantly have cation imbalances as a result of high magnesium $(\mathrm{Mg})$ but low calcium (Ca) (Proctor et al., 1981; Echevarria, 2018). This atypical soil chemistry has caused the occurrence of distinct vegetation types characterized by relatively low stature and high levels of endemicity (Brooks, 1987; Proctor, 2003; van der Ent et al., 2018). The main soil-edaphic factors that are most often cited to be important in relation to the ecology of ultramafic soils are the (potential) phytotoxicity induced by $\mathrm{Ni}$, and possibly by $\mathrm{Co}$ and $\mathrm{Cr}$, and nutrient deficiency as a result of low $\mathrm{Ca}$ (and high $\mathrm{Mg}$ ) and very low potassium $(\mathrm{K})$ and phosphorus (P) (Vlamis and Jenny, 1948; Walker, 1954; Proctor et al., 1981; Brooks, 1987; Proctor, 2003; Brady et al., 2005). Ecological studies have used single-stage soil extraction methods for: (i) Quantifying potential phytotoxic trace elements mainly Ni; (ii) Demonstrating (high) $\mathrm{Mg}: \mathrm{Ca}$ quotients in the CEC; and (iii) Estimating potentially plant-available P (Vlamis and Jenny, 1948; Proctor et al., 1981). Together these extractions aim to characterize the chemical properties of ultramafic soils under investigation with the ultimate objective of linking such information to ecological attributes, such as vegetation stunting, species-diversity per unit area or functional traits of individual species. However, none of the commonly used methods has been specifically developed for ultramafic soils, or for the use with regards to ecological parameters. Rather, most methods were originally developed for agricultural soils in relation to (trace element) nutrition and deficiency, or phytotoxicity risk assessments. Few studies have compared different methods in use in ecological studies on (tropical) ultramafic soils and evaluated the usefulness of such methods for the characterization of ultramafic soils.

\section{Chemical extraction methods for estimating potential soil trace element phytotoxicity}

Potentially phytoavailable trace element soil fractions can be estimated with a range of different methods, including: (a) Single-stage chemical extractants; (b) Sequential extractants schemes; (c) Ion exchange resin methods (IER); (d) Isotopic exchange kinetics (IEK); and (e) Diffusive Gradients in Thin-films (DGT) (Echevarria et al., 1998; Robinson et al., 1999). None of these methods, however, can exactly simulate trace elements availability to plants. Single-stage chemical extractants can be grouped in: (i) neutral salt-based extracts; (ii) chelator-based extracts; (iii) acid-based extracts; or (iv) synthetic root exudate-based extracts. 
Important parameters for all extraction methods are the molar concentration of the extract, the liquid to solid ratio, $\mathrm{pH}$, and the equilibration time (Meers et al., 2007).

Neutral salt-based extracts include $\mathrm{CaCl}_{2}, \mathrm{Ca}\left(\mathrm{NO}_{3}\right)_{2}, \mathrm{KCl}, \mathrm{NaNO}_{3}$, and $\mathrm{NH}_{4} \mathrm{Ac}$ in various molar concentrations. Initially, the aim for using such solutions was to assess the pool of exchangeable cations that are sorbed onto the Cation Exchange Capacity (CEC) (Ciesieslki and Sterckeman, 1997). The ion replacement power in such extract solutions (with identical anions, such as $\mathrm{NO}_{3}{ }^{-}$) decreases according to the $\mathrm{Z}$ number of the element in the order: $\mathrm{Ba}^{2+}>$ $\mathrm{Sr}^{2+}>\mathrm{Ca}^{2+}>\mathrm{Mg}^{2+}>\mathrm{NH}^{4+}>\mathrm{K}^{+}>\mathrm{Na}^{+}$(Mengel and Kirkby, 2001). The specific chemical adsorption of divalent cations by the soil phases is mainly related to metal ion hydrolysis and increases with increasing $\mathrm{pH}$ with $\mathrm{pK}$ values of the metal ion hydrolysis, for example 9.9 (Ni) and 9.7 (Co) (Brümmer et al., 1986). However, ion exchange in soils is also indirectly influenced by soil $\mathrm{pH}$ because of the competition with $\mathrm{H}^{+}$ions for sorption onto the CEC (Tiller et al., 1984). Neutral salt extracts based on monovalent and divalent cations are essentially pH dependent (Anderson and Christensen, 1988; Echevarria et al., 2006), and have been reported to perform better than methods using chelators or methods that significantly acidify or buffer the soil, altering the $\mathrm{pH}$ at which the extraction actually occurs (Menzies et al., 2007). Frequently used are 0.01 or $0.1 \mathrm{M} \mathrm{CaCl}_{2}$ solutions; and at the ionic strength of 0.01 $\mathrm{M}$ the extractant solution has a similar ionic strength to that of most soil solutions (Novozamsky et al., 1993; Houba et al., 2000). However, although in most 'normal' soils $\mathrm{Ca}^{2+}$ is the dominant cation, in ultramafic soils $\mathrm{Mg}^{2+}$ is generally the dominant cation, and hence an extractant based on $\mathrm{Mg}^{2+}$ might be more appropriate. Because $\mathrm{Cl}^{-}$is a complexing anion to some metals as opposed to the $\mathrm{NO}_{3}{ }^{-}$counter ion (Gommy et al., 1998), and because the $\mathrm{pH}$ can be shifted by high $\mathrm{Ca}^{2+}$ levels, $0.1 \mathrm{M} \mathrm{Sr}\left(\mathrm{NO}_{3}\right)_{2}$ (Wang et al. 2003) and $0.01 \mathrm{M}$ $\mathrm{Sr}\left(\mathrm{NO}_{3}\right)_{2}$ (Kukier and Chaney, 2004; Kukier et al., 2004) have also been proposed. In both the $\mathrm{CaCl}_{2}$ and $\mathrm{Sr}\left(\mathrm{NO}_{3}\right)_{2}$ extracts, the divalent cations also promote coagulation of the colloidal material in the suspension, making higher molar concentrations that are required for monovalent cations $\left(\mathrm{Na}^{+}, \mathrm{K}^{+}, \mathrm{NH}^{4+}\right)$ unnecessary (Meers et al., 2007). The $0.01 \mathrm{M}$ $\mathrm{Sr}\left(\mathrm{NO}_{3}\right)_{2}$ extraction has proven to be effective in predicting extractable $\mathrm{Ni}$ and plant $\mathrm{Ni}$ uptake across a range of soils (Siebielec et al., 2007). In many studies pertaining ultramafic soils, $1 \mathrm{M} \mathrm{NH} \mathrm{NH}_{4} \mathrm{Ac}(\mathrm{pH}$ 7.0) has been used for phytoavailable trace elements, and concomitantly for exchangeable cations (Proctor et al., 2000; Robinson et al., 2003; Brearley, 2005). Compared to divalent cations, $\mathrm{NH}_{4}{ }^{+}$is less competitive for desorption of metals from the solid soil phases, but performs similar to $\mathrm{K}^{+}$on account of its nearly identical ion radius 
(Gryschko et al., 2005; Gommy et al., 1998). The extractant is commonly buffered at pH 7 to prevent carbonate dissolution, but due to the increasing formation of $\mathrm{NH}_{3}$ from $\mathrm{NH}_{4}{ }^{+}$by dissociation with rising $\mathrm{pH}$, metal ammine complexes can form (Gryschko et al., 2005). This might be important (but has not been studied) in the case of ultramafic soils, with high concentrations of $\mathrm{Ni}^{2+}$, and the use of $\mathrm{NH}_{4} \mathrm{Ac}$ has strong effect on soil extract $\mathrm{pH}$ and might also result in the formation of soluble Ni-hexammine complexes, which can potentially result in overestimation of exchangeable soil Ni. Also, in acidified ultramafic soils, buffering the extraction solution at $\mathrm{pH} 7$ (2-3 units higher than soil $\mathrm{pH}$ ) can generate $\mathrm{CEC}$ of Fe-oxides and change the retention of metal cations by these minerals, which dominate the soil composition (Becquer et al., 2001).

Chelator-based extractants based on synthetic amino-polycarboxylic acids include EDTA and DTPA. The DTPA (Diethylene triamine pentaacetic acid) method was originally developed to diagnose deficiency of micronutrients in soils (Lindsay and Norvell, 1978), but has been widely used for studies with ultramafic soils (L'Huillier and Edighoffer, 1996; Echevarria et al., 1998, 2006; Lazarus et al., 2011; Chardot-Jacques et al., 2013; Ünver et al., 2013). The DTPA-extract is made up of $0.005 \mathrm{M}$ DTPA with $0.01 \mathrm{M} \mathrm{CaCl}_{2}$ and is buffered at $\mathrm{pH} 7.3$ with $0.01 \mathrm{M}$ triethanolamine (TEA). The extraction of trace elements in this extract is promoted by the chelation action of DTPA and the $\mathrm{Ca}^{2+}$ exchange with other cations, as well as $\mathrm{Cl}^{-}$complexation (Lindsay and Norvell, 1978; Hsiao et al., 2009). The buffer (TEA) was designed to prevent carbonate dissolution (Lindsay and Norvell, 1978), but carbonates are not likely to be important in ultramafic soils with $\mathrm{pH} 4-5.8$, and Becquer et al. (1995) proposed unbuffered (excluding TEA) DTPA adjusted to $\mathrm{pH}$ 5.3. It is, however, important to keep the Ca:DTPA ratio intact because Ca:DTPA binding is necessary to control the exchangeability and chelation of DTPA (Lindsay and Norvell, 1978). The DTPA method was developed for soil deficient in trace elements, whereas ultramafic soils have a surplus of $\mathrm{Ni}$, hence the DTPA-method risks over-saturation and the soil-extractant ratio needs to be adjusted accordingly (Kukier and Chaney, 2001; Li et al., 2000). Although some studies found (weak) correlation between soil Ni-DTPA and uptake in non-accumulating plants (L'Huillier and Edighoffer, 1996), such correlations are mostly restricted to comparing similar soils with a narrow pH range (Sukkariyah et al., 2005), and when applied to a variety of soils, poor prediction of phytoavailability has been reported (Menzies et al., 2007). This can be explained by the rather high chelation stability constants of Ni-DTPA and Co-DTPA at log K >20.2 and 19.3 respectively (Anderegg et al., 2005), which is unlikely representative for the chelation 
capacities of carboxylic acids (for example citrate-Ni $\log \mathrm{K} 5.4$ ) in the plant rhizosphere. However, DTPA-extractable Ni can, in some cases, be strongly correlated to Ni uptake by hyperaccumulators in a limited range of $\mathrm{pH}$ (i.e. 4.2 to 5.6) in temperate ultramafic soils (Chardot et al., 2007), whereas it is not the case in circum-neutral Mediterranean ultramafic soils (Bani et al., 2009). However, in all these soils, the Ni-DTPA appears to be a useful extractant of the exact isotopically-exchangeable pools from which all plants take up $\mathrm{Ni}$ (Massoura et al., 2004; Chardot et al., 2007; Estrade et al., 2015): i.e. high-activity clays and hydrous Fe oxides (Massoura et al., 2006; Chardot et al., 2007; Bani et al., 2009, 2014).

Acid-based extracts include a digest, normally microwave-pressure-aided or in a hot block with mineral acids such as $\mathrm{HCl}$ and $\mathrm{HNO}_{3}$. These extracts are used to provide 'pseudo-total' levels by dissolution of oxides, hydroxides, carbonates, organic matter and, if HF is also added to mix, to provide 'near-total' values by also breaking down silicate matrices. Such a digest gives a measure for virtually all trace elements present in the soil. In more dilute form, $\mathrm{HNO}_{3}(0.1 \mathrm{M})$ can also be used to leach metals from the soils, and this has the benefit that the $\mathrm{NO}_{3}{ }^{-}$counter ion is not complexing. Alternatively (very) dilute organic acids (such as acetic, citric, formic, lactic and malic acid) can be used to mimic plant root exudates as these acids are the most abundant Low Molecular Weight Organic Acids (LMWOA) present in the rhizosphere of many plants (Meers et al., 2007). Wang et al. (2003) and Feng et al. (2005) proposed $10 \mathrm{mM}$ LMWOA extraction solutions, consisting of formic acid, citric acid and malic acids, and reported good correlations with plant metal uptake. The acidity of these organic acids dissolutes hydroxides and carbonates, and the citrate and malate counter ions complex Ni and other trace elements. However, the evidence for dilute solutions of carboxylic acids being suitable extractants for metals remains weak.

Selective sequential extractions (SSE) provide operationally defined solid-phase fractionations of metals over soil pools (Quantin et al., 2002). Various schemes have been proposed based on the (much simpler) BCR-protocol (Quevauviller et al., 1994), but for trace elements $(\mathrm{Ni}, \mathrm{Co}, \mathrm{Cr})$ in ultramafic soils, the most reported is a 7-step programme that consists of the following stages: (1) Water soluble; (2) Exchangeable; (3) bound to Mn oxides; (4) Bound to amorphous Fe oxides; (5) Bound to crystalline Fe oxides; (6) Bound to organic matter; (7) and Residual (Quantin et al., 2002). Of these fractions, the water soluble and exchangeable are immediately phytoavailable, the fraction bound to $\mathrm{Mn}$ oxides, amorphous Fe oxides and bound to organic matter are potentially phytoavailable, whereas the 
residual faction is not phytoavailable. Together these labile and non-labile pools determine the mobility and phytoavailability of $\mathrm{Ni}, \mathrm{Cr}$ and $\mathrm{Co}$ in ultramafic soils. Some of these labile fractions extracted individually (and not through a complete sequential procedure) from a wide range of ultramafic soils have been proved to be strongly correlated to isotopicallyexchangeable Ni pools, which is the principal source of $\mathrm{Ni}$ available to plants in soils: e.g. amorphous Fe oxides (Massoura et al., 2004, 2006).

In this study, ultramafic soil samples were collected from a $700-\mathrm{km}^{2}$ area encompassing Kinabalu Park in Malaysia. These soil samples were analysed with the aims of characterizing soil chemical properties, in particular those of ecological relevance to plants, such as the cation exchange complex, availability of macro-nutrients, and concentrations of extractable trace elements. To that end, we compare and evaluate the results of a range of extraction methods commonly used in the field of tropical ecology with a focus on predictive power for characterizing soils, interrelatedness and ecological application.

\section{MATERIALS AND METHODS}

\section{Study area and sample collection}

Mount Kinabalu Park is located in Sabah (Malaysia) on the island of Borneo $\left(6^{\prime} 5^{\prime} \mathrm{N}\right.$ and $\left.160^{\prime} 33^{\prime} \mathrm{E}\right)$, covering an area of $754 \mathrm{~km}^{2}$ including two mountains: Kinabalu (4095 m) and Tambuyukon $(2579 \mathrm{~m})$. Although Mount Kinabalu itself is a granite pluton (Cottam et al., 2010), the lower slopes are covered with sedimentary rocks. Ultramafic rock outcrops appear like a collar around the massif on mid-elevation, and also outcrops on Mount Tambuyukon. In total, ultramafic outcrops cover $142 \mathrm{~km}^{2}$ within the Park boundaries (Collenette, 1964). Kinabalu Park is covered with intact rainforest and has a humid tropical climate with a mean monthly air temperature of $20^{\circ} \mathrm{C}$ throughout the year at $1680 \mathrm{~m}$, with a daily fluctuation of 7$9^{\circ} \mathrm{C}$ (Kitayama, 1991).

During 2010-2014, a large ecological research project was conducted in Kinabalu Park, and in the nearby Bidu-Bidu Hills and Trus Madi Forest Reserves, all in the Malaysian state of Sabah. The project was wide-ranging, but focused on the plant-soil relationships of the vegetation on ultramafic soils at these localities. Data from these soil samples has been previously reported (Van der Ent et al., 2015a,b; 2016a,b; 2018) and we refer to these publications for full details on the sample collection. Briefly, the soil samples were collected 
from 14 different ultramafic localities (474-2950 m asl) in Kinabalu Park, including in total 95 discrete sample sites. At each site, 3 soil samples $(1-2 \mathrm{~kg})$ were collected in the $\mathrm{A} / \mathrm{B}$ mineral horizon, and care was taken not to include organic surface layers. All soil samples were packed, brought to the local field station, air-dried at room temperature to constant weight (2-3 weeks), sieved to $<2 \mathrm{~mm}$, shipped to Australia, and gamma irradiated at Steritech Pty. Ltd. in Brisbane following Australian Quarantine Regulations.

\section{Laboratory analyses}

The chemical analysis of the soil samples took place in the laboratory of the Centre for Mined Land Rehabilitation (CMLR) at The University of Queensland in Australia. The soil samples $(0.3 \mathrm{~g})$ were digested using freshly prepared Aqua Regia (4 mL 70\% nitric acid and $3 \mathrm{~mL}$ $37 \%$ hydrochloric acid per sample) in a digestion microwave for a 1-hour programme and diluted to $45 \mathrm{~mL}$ before analysis (Rayment and Higginson, 1992; method 17B1). Soil pH and electrical conductivity (EC) was obtained in a 1:2.5 soil:water mixture after 1-hour equilibrium time on an end-over-end shaker and 1-hour settling time. Plant-available phosphorus as Olsen-P (Olsen et al., 1954) was extracted with $1.0 \mathrm{~g}$ soil extracted with $20 \mathrm{~mL}$ $0.5 \mathrm{M} \mathrm{NaHCO}_{3}$ (pH 8.5) for 30 minutes (Rayment and Higginson, 1992; method 9C1). Plantavailable phosphorus ('ML-3') was also extracted with Mehlich-3 solution consisting of (0.2 $\mathrm{M} \mathrm{CH} \mathrm{CHOH}_{3} \mathrm{CO}+0.25 \mathrm{M} \mathrm{NH}_{4} \mathrm{NO}_{3}+0.015 \mathrm{M} \mathrm{NH}_{4} \mathrm{~F}+0.013 \mathrm{M} \mathrm{HNO}_{3}+0.001 \mathrm{M}$ EDTA at $\mathrm{pH}$ $2.50 \pm 0.05$ ), according to Mehlich (1984). This method is also used for phytoavailable trace elements, and as such provides a 'multi-functional' extract. Exchangeable trace elements $(\mathrm{Ni}$, $\mathrm{Co}, \mathrm{Cr}, \mathrm{Mn})$ were extracted in $0.1 \mathrm{M} \mathrm{Sr}\left(\mathrm{NO}_{3}\right)_{2}$ at a soil:solution ratio of 1:4 (10 g:40 mL) and 2-hour equilibrium time (Wang et al., 2003). This method was repeated on a selection of 25 samples using $0.01 \mathrm{M} \mathrm{Sr}\left(\mathrm{NO}_{3}\right)_{2}$ for a comparison. In addition, a second method for exchangeable trace elements was used with $0.01 \mathrm{M} \mathrm{CaCl}_{2}$ separately with 2-hours equilibrium time (Houba et al. 2000; Meers et al., 2007). This method was also repeated on the same selection of 25 samples used in the $\operatorname{Sr}\left(\mathrm{NO}_{3}\right)_{2}$ method using $0.1 \mathrm{M} \mathrm{CaCl}_{2}$.

Potentially phytoavailable trace elements $(\mathrm{Ni}, \mathrm{Co}, \mathrm{Cr}, \mathrm{Mn})$ were extracted with standard Diethylene triamine pentaacetic acid (DTPA) according to Lindsay and Norvell (1969), and also (separately) using an adaptation by Becquer et al. (1995), which excluding TEA, was adjusted to $\mathrm{pH} 5.3$ and had an equilibrium time of 2-hours (instead of 1-hour). Another method for potentially phytoavailable trace elements was also used, by extraction with a mixture of carboxylic acids (acetic, malic and citrate acid in molar ratio of 1:2:2 at $0.01 \mathrm{M}$ ) at 
a soil:solution ratio of 1:4 (10 g:40 mL) and 2-hour shaking equilibrium time (method loosely based on Feng et al., 2005). Exchangeable cations were extracted with silver-thiorea (Dohrmann, 2006) over a 16-hour equilibrium time on an end-over-end shaker in the dark (to prevent silver precipitation). In addition, a second method for exchangeable cations, the traditional $1 \mathrm{M}$ pH 7.0 ammonium acetate $\left(\mathrm{NH}_{4} \mathrm{Ac}\right)$ was used with 2-hours equilibrium time (Meers et al., 2007).

All soil extractions were undertaken in disposable $50 \mathrm{~mL}$ polypropylene (PP) centrifuge tubes. Soil samples were weighed using a 4-decimal balance and weights recorded for correction of the precise weights in the mass balance calculations. All samples were agitated ('equilibrated') for method-specific times using an end-over-end shaker at $60 \mathrm{rpm}$ and subsequent centrifuged (10 minutes at $4000 \mathrm{rpm}$ ) and the supernatant was collected in $10 \mathrm{~mL}$ polyethylene tubes. The extraction methods and operational conditions are given in Table 1 .

Nickel, Co and Cr partitioning was evaluated with a 5-step selective sequential extraction scheme to provide operationally defined solid-phase trace element ( $\mathrm{Ni}, \mathrm{Cr}, \mathrm{Co}, \mathrm{Mn}$ ) fractionation. This scheme is based on Quentin et al. (2002), which was in turn modified mainly from Leleyter and Probst (1999). Adaptations were made here by combining step 1 and step 2, and by using $\mathrm{HNO}_{3} / \mathrm{HF}$ high-pressure microwave digests for the residual fraction (step 5) instead of an alkaline fusion as in Quentin et al. (2002). The step for the 'organic bound phase' was also omitted because the tested soils were extremely low in organic matter. As such the fractions were: water soluble and exchangeable (i), bound to Mn oxides (ii), bound to amorphous Fe oxides (iii), bound to crystalline Fe oxides (iv), and residual (v). After each extraction step, the tubes were centrifuged for 10 minutes at $4000 \mathrm{rpm}$ and the supernatants were then filtered through $0.45 \mu \mathrm{m}$ membranes. The residues were washed with $20 \mathrm{~mL}$ of TDI water, centrifuged again for 10 minutes at $4000 \mathrm{rpm}$, the water decanted, and the residue dried at $40^{\circ} \mathrm{C}$ prior to the next extraction step. The different extraction phases and operational conditions are presented in Table 2.

All soil extracts samples were analyzed with Inductively Coupled Plasma Atomic Emission Spectroscopy (ICP-AES) (Varian Vista Pro II) for Ni, Co, Cu, Zn, Mn, Fe, Mg, Ca, Na, K, S and P. Each method included 3 sample blanks, 2 NIST standards, 2 ASPAC reference soils, 3 random sample duplicates and 3 multi-element standards as part of the quality control. The ICP-AES instrument was calibrated using a 6-point multi-element standard (which included all measured elements) prepared in each extraction solution. 


\section{Statistical analysis}

The soil chemistry data was analysed using the software package STATISTICA Version 9.0 (StatSoft), Excel for Mac version 2011 (Microsoft) and PRIMER Version 6 (PRIMER-E).

\section{RESULTS}

\section{Extraction methods}

In the context of ultramafic soils, the most frequently used extraction methods to estimate potentially phytoavailable $\mathrm{Ni}$, Co and other trace elements are the DTPA-extract, $\mathrm{NH}_{4} \mathrm{Ac}$ extract, $\mathrm{CaCl}_{2}$ extract and the $\mathrm{Sr}\left(\mathrm{NO}_{3}\right)_{2}$ extract (McLaughlin et al. 2000; Kukier and Chaney, 2001; Wang et al. 2006). Of these DTPA-TEA, DTPA, $1 \mathrm{M} \mathrm{NH}_{4} \mathrm{Ac}, 0.01 \mathrm{M}$ and $0.1 \mathrm{M} \mathrm{CaCl}_{2}$, $0.1 \mathrm{M}$ and $0.01 \mathrm{M} \mathrm{Sr}\left(\mathrm{NO}_{3}\right)_{2}$, were tested here, in addition to the Mehlich-3 extract and a 0.01 M mix of carboxylic acids. Figure 1 compares the different extraction methods for the amounts of $\mathrm{Ni}, \mathrm{Cr}$ and $\mathrm{Co}$ extracted. Extractable amounts of $\mathrm{Cr}$ are extremely low for all extractants, but the acid-based extractants released the most $\mathrm{Cr}$. The greatest amounts of $\mathrm{Ni}$ and Co were extracted with acid-based extracts, and relatively large amounts were also extracted with DTPA. Nickel is moderately extractable $(3.5 \%$ of the mean pseudo-total soil $\mathrm{Ni})$, but $\mathrm{Cr}$ was almost completely unavailable $(0.009 \%$ of the mean pseudo-total soil $\mathrm{Cr})$ in the DTPA extracts (Table 3). Figure 2 shows correlation for Co and Ni between DTPA extract and other extracts $\left(0.1 \mathrm{M} \mathrm{CaCl}_{2}, 0.1 \mathrm{M} \mathrm{Sr}\left(\mathrm{NO}_{3}\right)_{2}\right.$ and Mehlich-3). For the Co and $\mathrm{Ni}$, relatively high correlation exists between the DTPA and Mehlich-3 extracts, followed by $\mathrm{CaCl}_{2}$, but low correlation with the $\mathrm{Sr}\left(\mathrm{NO}_{3}\right)_{2}$ extract (Supplementary Fig. 1).

\section{Buffered and unbuffered DTPA extractions}

Unbuffered DTPA (excluding TEA, pH 5.3) was used for all soils $(\mathrm{n}=343)$ and buffered DTPA (including TEA, pH 7.3) on a subset of soils $(\mathrm{n}=93)$. Both methods correlate well $(r=$ 0.75 for $\mathrm{Co}, 0.59$ for $\mathrm{Cr}, 0.84$ for $\mathrm{Mn}$, and 0.80 for $\mathrm{Ni}$; at $p<0.01$ ), but the buffered DTPA extracts had considerably more $\mathrm{Ni}$, Co and Mn compared to unbuffered DTPA, indicating the role of extraction solution $\mathrm{pH}$ in the extraction method.

\section{$\mathrm{Sr}(\mathrm{NO3})_{2}$ and $\mathrm{CaCl}_{2}(0.1$ and $0.01 \mathrm{M})$ extractions}

The $0.1 \mathrm{M}$ and $0.01 \mathrm{M} \mathrm{Sr}\left(\mathrm{NO}_{3}\right)_{2}$ and $0.1 \mathrm{M}$ and $0.01 \mathrm{M} \mathrm{CaCl}_{2}$ extractants were tested on a selection of 25 samples, as it was predicted that the higher molarity would result in higher extractable levels of $\mathrm{Ni}$ and $\mathrm{Co}$ (hence better detection precision during ICP-AES analysis), 
but would also induce a stronger drop in $\mathrm{pH}$ due to displacement of $\mathrm{H}^{+}$. Comparing $0.01 \mathrm{M}$ $\mathrm{CaCl}_{2}$ with $0.1 \mathrm{M} \mathrm{Sr}\left(\mathrm{NO}_{3}\right)_{2}$ shows a very good correlation $(r=0.99)$, and a good correlation $\left(r=0.82\right.$ at $p<0.01$ ) was obtained for $0.1 \mathrm{M} \mathrm{CaCl}_{2}$ versus $0.1 \mathrm{M} \mathrm{Sr}\left(\mathrm{NO}_{3}\right)_{2}$ (Fig. 3). In both cases, the $\operatorname{Sr}\left(\mathrm{NO}_{3}\right)_{2}$ extracts had greater amounts of $\mathrm{Ni}$ (up to a factor 3), which can be explained by the greater cation displacement power for $\mathrm{Sr}^{2+}$ compared to $\mathrm{Ca}^{2+}$ at the same molar concentration. The change in $\mathrm{pH}$ in both extracts is somewhat erratic (in relation to the extracted amount of Ni) but vary little between the extractants. Calcium or Sr concentration does affect competition with sorption and $\mathrm{pH}$ of the extraction fluid which clearly affects extractable Ni (Fig. 3).

\section{Multivariate regression of independent parameters}

Soil extraction methods generally benefit from having factors for prediction of plant response such as soil $\mathrm{pH}$ and CEC incorporated in the multivariate regression model to increase accuracy (Haq et al., 1980; Meers et al., 2007 Siebielec et al., 2007; Römkens et al., 2009). Here we use a multivariate regression expressing extractable $\mathrm{Ni}$ or Co contents as a function of independent factors using the following equation:

$\log \left(\mathrm{M}_{\text {extraction }}\right)=\alpha \log \left(\mathrm{M}_{\text {total }}\right)+\beta \mathrm{pH}+\gamma \log (\mathrm{CEC})+\delta$

$\mathrm{M}_{\text {extraction }} \quad$ Metal extracted in $\mu \mathrm{g} \mathrm{g}^{-1}$

$\mathrm{M}_{\text {total }} \quad$ Pseudo-total metal concentration ( $\mathrm{HNO}_{3} / \mathrm{HCl}$-digest) in $\mu \mathrm{g} \mathrm{g}^{-1}$

$\mathrm{pH} \quad$ Measured soil $\mathrm{pH}$

CEC Soil CEC in $\mathrm{mmol}^{(+)} \mathrm{kg}^{-1}$

$\alpha, \beta, \gamma$ and $\delta$ are constants

All independent input variables were log-transformed (except for $\mathrm{pH}$, which is already logtransformed) prior to regression analysis. The regression equation provides empirical information on relevant factors influencing $\mathrm{Ni}$ or Co extractability using various extractants, thus allowing for the identification of the most influencing of these factors. We tested various factors, including $\mathrm{pH}, \mathrm{EC}, \mathrm{CEC}$, pseudo-total metal concentrations and extractable metal concentrations (other than $\mathrm{Ni}$ or $\mathrm{Co}$ ), but after evaluating the fits only $\mathrm{pH}, \mathrm{CEC}$ and pseudototal metal concentrations provided improved predictability. Table 4 and 5 lists the calculated factors and constants for the multivariate analysis, and it is clear that in most cases pseudototal $\mathrm{Ni}$ or $\mathrm{Co}$ is the single most important factor predicting extractability in the extracts. 


\section{Sequential extraction for trace element partitioning}

Selective sequential extractions show that $\mathrm{Cr}$ is mainly associated with crystalline Fe-oxides, explaining its low extractability in the $\mathrm{Sr}\left(\mathrm{NO}_{3}\right)_{2}$ and DTPA extracts. However, $\mathrm{Ni}$ and Co are mainly bound in the Mn-oxides and most of all in amorphous Fe-oxides fractions and hence are more phytoavailable, as is evident from higher concentrations in the $\operatorname{Sr}\left(\mathrm{NO}_{3}\right)_{2}$ and DTPA extracts. Table 6 shows relative portions of $\mathrm{Ni}$, Co and $\mathrm{Cr}$ over the 5 fractions of the selective extraction procedure.

\section{Cation Exchange capacity (CEC) and component ions}

Figure 4 shows K extractability in silverthiorea (AgTU) extract versus K in Mehlich-3 (ML3), $0.1 \mathrm{M} \mathrm{Sr}\left(\mathrm{NO}_{3}\right)_{2}$ and carboxylic acid (CA) extracts. These extraction methods are highly intercorrelated for $\mathrm{K}$, and for $\mathrm{Ca}$ and $\mathrm{Mg}$ (data not shown), and therefore all could be used for measuring cation exchange capacity and component ions. This has major benefits, as combining methods (for example the carboxylic acid extract) for both cations and trace elements reduces time and costs.

\section{Plant available phosphorus}

Olsen-P and Mehlich-3 extractions are relatively poorly correlated ( $r=0.41$ at $p<0.01$ ), but given that the majority of the ultramafic soils are between $\mathrm{pH}$ 3.76-5.5, the Mehlich-3 method appears more appropriate. However, for near-neutral $\mathrm{pH}$ ultramafic soils, the Olsen-method would be more likely to be related to plant available P than the Mehlich-method.

\section{DISCUSSION}

Although ultramafic soils are enriched in the trace elements $\mathrm{Ni}, \mathrm{Co}, \mathrm{Cr}$, and $\mathrm{Mn}$, phytoavailable concentrations of these elements are only a fraction of the pseudo-total concentrations present in the soil. Nevertheless, these elements are potentially present at phytotoxic concentrations and are widely seen as important factors contributing to the adversity of strongly acidic ultramafic soils to plants (Crooke and Inkson, 1955; Kukier and Chaney, 2003). In addition, major cation imbalance towards $\mathrm{Mg}$ and the deficit in $\mathrm{Ca}, \mathrm{N}, \mathrm{P}$ and $\mathrm{K}$ are also thought to be major factors affecting plants growing in these soils (Walker et al., 1955; Brooks, 1987; Nagy and Proctor, 1997; Echevarria, 2018). The high geodiversity of Mount Kinabalu Park, a result of complex geology, paleo-history, topography and climate, has created ultramafic soils that are extremely diverse in their pedology and chemical properties (van der Ent et al., 2018). Appropriate chemical characterization of these soils is 
therefore a challenge. Unfortunately, most chemical extractants used for characterizing soils (trace elements, nutrient status and cation exchange complex) were historically developed for agricultural soils with restricted ranges of main properties, or within ecotoxicological frameworks, and the appropriateness for using such methods for estimating ecological effects on plants growing in tropical ultramafic soils is questionable. Although there is only limited knowledge of the precise chemical interactions of these extractions in ultramafic soils, most extraction methods tested here perform well in characterizing different types of ultramafic soils. In ultramafic soils, Ni is mainly associated with low-charge (serpentine, talc) and highcharge (smectite) clays, with Fe-(Mn) oxides and with Layered Double Hydroxide (LDH) phase minerals (Siebecker and Sparks, 2010), but there is no extraction method specific for these phases, although $\mathrm{Ni}$ may be (partly) co-extracted in existing methods. However, exchangeable $\mathrm{Al}$ and $\mathrm{Mg}$ are more important in the case of the carboxylic and DTPA extractable Ni. This can be explained by the presence of Layered Double Hydroxide (LDH) phase minerals that can adsorb $\mathrm{Ni}$, and from which the carboxylic acid and DTPA extractants can desorb (part of the) Ni. In the unbuffered salt extracts $\left(\operatorname{Sr}\left(\mathrm{NO}_{3}\right)_{2}\right)$, soil $\mathrm{pH}$ is an important factor. This $\mathrm{pH}$-dependence is not surprising because this extractant essentially represents solubility of $\mathrm{Ni}$ at soil $\mathrm{pH}$. Regarding $\mathrm{Cr}$, strong chelating agents (as anions) can desorb $\mathrm{CrVI}$ anions. In the case of DTPA, it is interesting to note that acid $\mathrm{pH}$ mobilizes less $\mathrm{Cr}$ than higher $\mathrm{pH}$. This fits well with the fact that anions are more easily desorbed at higher $\mathrm{pH}$. When $\mathrm{Mn}$ is highly available, $\mathrm{Cr}^{3+}$ can be oxidized by reducing MnIV into MnII. CrVI is then complexed onto the surface of Fe-oxides, and therefore desorbed by DTPA or carboxylates such as citrate, which in turn adsorb onto the surface of Fe-oxides such as other anionic extractants, e.g. phosphate (Raous et al., 2013).

Exchangeable cations are fundamental to buffering soil $\mathrm{pH}$ and hence directly and indirectly influence many soil processes. CEC soil extraction methods rely on attempting to displace all exchangeable cations. Exchangeable cations are often measured with the $1 \mathrm{M}$ pH 7.0 ammonium acetate $\left(\mathrm{NH}_{4} \mathrm{Ac}\right)$ method (DIN, 1995), with cobalt(III) hexamine trichloride method (Cisielski and Sterckeman, 1997; in the case of ultramafic soils: Raous et al., 2013) or the silverthiorea method (Pleysier and Juo, 1980; Searle, 1986; Dohrmann, 2006). The second method is not adapted to evaluate exchangeable Co in ultramafic soils. The last is, however, not frequently used for ultramafic soils, but has the benefit over $\mathrm{NH}_{4} \mathrm{Ac}$ as it adopts the $\mathrm{pH}$ of the soil solution, has a greater cation displacement power, and exchange takes place at low ionic strength (0.01 M) (Pleysier and Juo, 1980; Proctor et al., 1981). As is typical for 
ultramafic soils, the cation exchange complex is saturated with $\mathrm{Mg}^{2+}$, but absolute concentrations of $\mathrm{Ca}^{2+}$ are not always low. The total cation exchangeable capacity (CEC) is lowest in the strongly leached Ferralsols, and high to extremely high in hypermagnesic Leptosols and serpentinitic Cambisols (Echevarria, 2018; van der Ent et al., 2018).

Apart from pseudo-total $\mathrm{P}$ (acid digest), $\mathrm{P}$ was extracted with the Olsen-P and Mehlich-3 methods, aimed at quantifying approximate plant available $\mathrm{P}$ concentrations. The Olsen-P method was initially developed for calcareous soils as the extraction solution is $\mathrm{pH} 8.5$ (Sharpley et al., 2008), whereas the Mehlich-3 method was developed for non-calcareous soils with an extractant solution of $\mathrm{pH} 2.5$ (Mehlich, 1984). The Mehlich-3 method is similar to the Bray-1 method as both employ a dilute $\mathrm{NH}_{4} \mathrm{~F}$ extraction medium (Lucero et al. 1998). Olsen $\mathrm{P}$ was proved to selectively extract isotopically-exchangeable $\mathrm{P}$ in a wide array of soils (Fardeau et al., 1988) which makes it a more universal method than initially thought.

A soil extraction method should be able to explain potential phytotoxicity effects as a result of trace elements, and should have predictive power for plant-uptake of these elements or at least a correlation with plant-uptake. However, plant uptake usually depends on the plant status and needs and may substantially vary between species. Even more, with high supply, plant uptake can respond without any correlation with the chemically mobile pool of an element (e.g. Ni for Alyssum murale in low pH soils: see Kukier et al., 2004; Bani et al., 2014). Ideally, the extractant provides simultaneous information about trace elements, exchangeable cations (major and trace) and macronutrients. Of the tested method, only Mehlich-3 method was specifically designed for such a 'multi-functional' purpose (Mehlich, 1984). This method uses dilute acetic acid combined with low concentration of EDTA for release and chelation of trace elements. Also present in the extraction solution are $\mathrm{NH}_{4} \mathrm{NO}_{3}$ to exchange cations from the exchange complex, and further $\mathrm{NH}_{4} \mathrm{~F}$ to extract $\mathrm{P}$ (hence essentially identical to the Bray-1 method of phytoavailable $\mathrm{P})$. The 0.01 and $0.1 \mathrm{M} \mathrm{Sr}\left(\mathrm{NO}_{3}\right)_{2}$ extracts appear to achieve more consistent results compared to other dilute neutral salt extracts $\left(0.01\right.$ and $\left.0.1 \mathrm{MM} \mathrm{CaCl}_{2}\right)$, and have been shown to correlate with immediate Ni phytotoxicity (Kukier and Chaney, 2001; Siebielec et al., 2007). The buffered and unbuffered DTPA methods are highly correlated, despite the fact that the unbuffered version is more adaptable to the soil $\mathrm{pH}$. The high correlation of the carboxylic acid method not only with DTPA, Mehlich-3, $\mathrm{CaCl}_{2}$ and $\mathrm{Sr}\left(\mathrm{NO}_{3}\right)_{2}$ extractable trace elements $(\mathrm{Ni}, \mathrm{Cr}, \mathrm{Co})$, but also with silverthiorea-CEC and silverthiorea exchangeable cations $(\mathrm{Ca}, \mathrm{Mg}, \mathrm{K})$ means that this method is well-suited for 
general characterization of tropical ultramafic soils. However, as with all methods tested here, ecological implications for tropical vegetation or elemental uptake in native plants growing in tropical ultramafic soils remains unstudied. Without plant uptake data, the predictive values of the soil extractions should be interpreted cautiously. Future research is required to assess suitable extraction methods for ultramafic soils by evaluating the correlation of extraction results with plant composition or deficiency, adequacy and toxicity of specific elements. There is the need to test whether the displaced soil solution extraction method (Proctor et al., 1981; Kukier et al., 2004; Coinchelin et al., 2012) could be useful in predicting short-term phytoavailability of trace elements in local ultramafic soils as it was shown that hyperaccumulators can concentrate $\mathrm{Ni}$ during active root uptake (up to five times) from the initial concentration in the displaced soil solution, that means, depletion of the labile pools is strongly active (Coinchelin et al., 2012). Furthermore, tropical ultramafic soils present suitable opportunity for use in $\mathrm{Ni}$ agromining (a technology that extracts strategic metals from the biomass of selected 'metal crops') (van der Ent et al., 2013b; 2015c). Hence, it is imperative to develop robust Ni phytoavailability assays to predict Ni yield in 'metal crops' as $\mathrm{Ni}$ accumulation by 'hypernickelophores' has little evident relationship with single soil extraction methods including displaced soil solution (Nkrumah et al., 2016). The fact that plant species native to (tropical) ultramafic soils have evolved while confronted with extreme soil chemistry means that they must be highly tolerant, and therefore the results from experimental trials using 'normal' plants are not immediately applicable. Finally, plants vary widely not only in their tolerance to soil chemistry, but also in their uptake characteristics of trace elements $(\mathrm{Ni}, \mathrm{Co}, \mathrm{Cr}, \mathrm{Mn})$ depending on genotypic and phenotypic controlled ecophysiologies (Ernst, 2006; Ünver et al., 2013), therefore aiming for a soil extraction method that accurately predicts the response of all plant species on ultramafic soils is futile. Rather the method of choice needs to be inexpensive and simple, comparable to existing literature, as well as applicable to a wide range of different ultramafic soils. These conditions are met specifically with the carboxylic acid method. For more complex hyperaccumulator crops, both a mild extraction that is related to soil chemistry and a more intense DTPA extractions might be relevant to assess both the initial pool in the soil solution (i.e., intensity) and the entire pool that replenishes the soil solution (i.e., quantity) under significant depletion exerted by hyperaccumulators (Echevarria et al., 1998, 2006; Coinchelin et al., 2012). 


\section{ACKNOWLEDGEMENTS}

We wish to thank Sabah Parks for their support and the SaBC for granting permission for conducting research in Sabah, and to extend our gratitude to Kalipin Al-Hafsan Bin Sampin and Hali bin Nassim in the field, and Vanessa Ullmann in the laboratory. The French National Research Agency through the national "Investissements d'avenir" program (ANR-10-LABX21, LABEX RESSOURCES21) and through the ANR-14-CE04-0005 Project "Agromine" is acknowledged for funding support to A. van der Ent and P.N. Nkrumah. A. van der Ent is the recipient of a Discovery Early Career Researcher Award (DE160100429) from the Australian Research Council. P.N. Nkrumah is the recipient of an Australian Government Research Training Program Scholarship and UQ Centennial Scholarship at The University of Queensland, Australia.

\section{REFERENCES}

Anderegg, G., Arnaud-Neu, F., Delgado, R., Felcman, J., Popov, K., 2005. Critical evaluation of stability constants of metal complexes of complexones for biomedical and environmental applications* (IUPAC Technical Report). Pure and Applied Chemistry 77(8), pp. 1445-1495.

Anderson, P.R., Christensen, T.H., 1988. Distribution coefficients of Cd, Co, Ni, and Zn in soils. Journal of Soil Science 39, pp. 15-22.

Bani, A., Echevarria, G., Mullaj, A., Reeves, R.D., Morel, J.L., Sulçe, S., 2009. Ni hyperaccumulation by Brassicaceae in serpentine soils of Albania and NW Greece. Northeastern Naturalist 16, pp. 385-404.

Bani, A., Echevarria, G., Montargès-Pelletier, E., Gjoka, F., Sulce, S., Morel, J.L., 2014. Pedogenesis and nickel biogeochemistry in a typical Albanian ultramafic toposequence. Environmental Monitoring and Assessment 186, pp. 4431-4442.

Becquer, T., Bourdon, E., Pétard, J., 1995. Disponibilité du nickel le long d'une toposéquence de sols développés sur roches ultramafiques de Nouvelle-Calédonie. Comptes rendus de l'Académie des sciences. Série 2. Sciences de la terre et des planètes 321(7), pp. 585-592. 
Becquer, T., Pétard, J., Duwig, C., Bourdon, E., Moreau, R., Herbillon, A.J., 2001. Mineralogical, chemical and charge properties of Geric Ferralsols from New Caledonia. Geoderma 103(3), pp. 291-306.

Becquer, T., Quantin, C., Sicot, M., Boudot, J., 2003. Chromium availability in ultramafic soils from New Caledonia. The Science of the Total Environment 301(1-3), pp. 251-261.

Brady, K.U., Kruckeberg, A.R., Bradshaw, H.D.Jr., 2005. Evolutionary ecology of plant adaptation to serpentine soils. Annual Review of Ecology, Evolution, and Systematics 36, pp. 243-266.

Brearley, F., 2005. Nutrient limitation in a Malaysian ultramafic soil. Journal of Tropical Forest Science 17(4), pp. 596-609.

Brooks, R.R., 1987. Serpentine and its vegetation: A multidisciplinary approach. Dioscorides Press, Portland, Oregon, USA.

Bruemmer, G.W., Gerth, J., Herms, U. 1986. Heavy metal species, mobility and availability in soils. Zeitschrift für Pflanzenernährung und Bodenkunde 149, pp. 382-398.

Chardot, V., Echevarria, G., Gury, M., Massoura, S., Morel, J.L., 2007. Nickel bioavailability in an ultramafic toposequence in the Vosges Mountains (France). Plant and Soil 293(1-2), pp. $7-21$.

Chardot-Jacques, V., Calvaruso, C., Simon, B., Turpault, M.-P., Echevarria, G., Morel, J.L., 2013. Chrysotile dissolution in the rhizosphere of the nickel hyperaccumulator Leptoplax emarginata. Environmental Science and Technology 47(6), pp. 2612-2620.

Coinchelin, D., Bartoli, F., Robin, C., Echevarria, G., 2012. Ecophysiology of nickel phytoaccumulation: a simplified biophysical approach. Journal of Experimental Botany 63(16), pp. 5815-5827.

Collenette, P., 1964. A short account of the geology and geological history of Mt Kinabalu. Proceedings of the Royal Society of London, Series B 161, pp. 56-63. 
Cottam, M., Hall, R., Sperber, C., Armstrong, R., 2010. Pulsed emplacement of the Mount Kinabalu granite, Northern Borneo. Journal of the Geological Society 167(1), pp. 49-60.

Crooke, W.M., Inkson, R., 1955. The relationship between nickel toxicity and major nutrient supply. Plant and Soil 6(1), pp. 1-15.

Ciesielski, H., Sterckeman, T., 1997. Determination of cation exchange capacity and exchangeable cations in soils by means of cobalt hexamine trichloride. Effects of experimental conditions. Agronomie 17(1), pp. 1-7.

Dohrmann, R., 2006. Cation exchange capacity methodology II: A modified silver-thiourea method. Applied Clay Science 34(1-4), pp. 38-46.

Echevarria, G., 2018. Genesis and behaviour of ultramafic soils and consequences for nickel biogeochemistry. In: Agromining: extracting unconventional resources from plants, Mineral Resource Reviews series, Van der Ent A, Echevarria G, Baker AJM, Morel JL (Eds.), Springer, Cham, pp. 135-156.

Echevarria, G., Morel, J.L., Fardeau, J.C., Leclerc-Cessac, E., 1998. Assessment of phytoavailability of nickel in soils. Journal of Environmental Quality 27, pp. 1064-1070.

Echevarria, G., Massoura, S., Sterckeman, T., Becquer, T., Schwartz, C., Morel, J.L., 2006. Assessment and control of the bioavailability of Ni in soils. Environmental Toxicology and Chemistry 25, pp. 643-651.

Ernst, W., 2006. Evolution of metal tolerance in higher plants. Forest Snow and Landscape Research 80(3), pp. 251-274.

Estrade, N., Cloquet, C., Echevarria, G., Sterckeman, T., Deng, T-H-B., Tang, Y-T., Morel, J.L., 2015. Weathering and vegetation controls on nickel isotope fractionation in surface ultramafic environments (Albania). Earth and Planetary Science Letters 423, pp. 24-25. 
Fandeur, D., Juillot, F., Morin, G., Olivi, L., Cognigni, A., Ambrosi, J.-P., et al. 2009. Synchrotron-based speciation of chromium in an Oxisol from New Caledonia: Importance of secondary Fe-oxyhydroxides. American Mineralogist 94(5-6), pp. 710-719.

Fardeau, J.C., Morel, C., Boniface, R., 1988. Why the Olsen method should be used to estimate available soil-phosphorus. Agronomie 8(7), pp. 577-584.

Feng, M., Shan, X., Zhang, S., Wen, B., 2005. A comparison of the rhizosphere-based method with DTPA, EDTA, $\mathrm{CaCl}_{2}$, and $\mathrm{NaNO}_{3}$ extraction methods for prediction of bioavailability of metals in soil to barley. Environmental Pollution 137(2), pp. 231-240.

Garnier, J., Quantin, C., Martins, E.S., Becquer, T., 2006. Solid speciation and availability of chromium in ultramafic soils from Niquelāndia, Brazil. Journal of Geochemical Exploration 88(1-3), pp. 206-209.

Gommy, C., Perdrix, E., Galloo, J.-C., Guillermo, R., 1998. Metal speciation in soil: extraction of exchangeable cations from a calcareous soil with a magnesium nitrate solution. International Journal of Environmental Analytical Chemistry 72(1), pp. 27-45.

Gryschko, R., Kuhnle, R., Terytze, K., Breuer, J., Stahr, K., 2004. Soil extraction of readily soluble heavy metals and As with $1 \mathrm{M} \mathrm{NH}_{4} \mathrm{NO}_{3}$-Solution - Evaluation of DIN 19730 (6 pp). Journal of Soils and Sediments 5(2), pp. 101-106.

Hara, T., Sonoda, Y., 1979. Comparison of the toxicity of heavy metals to cabbage growth. Plant and Soil 51(1), pp. 127-133.

Haq, A.U., Bates, T.E., Soon, Y.K., 1980. Comparison of extractants for plant-available zinc, cadmium, nickel, and copper in contaminated soils. Soil Science Society of America Journal, 44(4), pp. 772-777.

Houba, V.J.G., Temminghof, E.J.M., Gaikhorst, G.A., van Vark, W., 2000. Soil analysis procedures using $0.01 \mathrm{M}$ calcium chloride as extraction reagent. Communications in Soil Science and Plant Analysis, 31 (2000), pp. 1299-1396. 
Hsiao, K.H., Bao, K.H., Wang, S.H., Hseu, Z.Y., 2009. Extractable concentrations of cobalt from serpentine soils with several single-extraction procedures. Communications in Soil Science and Plant Analysis 40(13-14), pp. 2200-2224.

Kukier, U., Chaney, R.L., 2001. Amelioration of nickel phytotoxicity in muck and mineral soils. Journal of Environmental Quality 30(6), pp. 1949-1960.

Kukier, U., Chaney, R.L., 2003. In situ remediation of nickel phytotoxicity for different plant species. Journal of Plant Nutrition 27(3), pp. 465-495.

Lazarus, B.E., Richards, J.H., Claassen, V.P., O’Dell, R.E., Ferrell, M.A., 2011. Species specific plant-soil interactions influence plant distribution on serpentine soils. Plant and Soil 342(1-2), pp. 327-344.

Latham, M., 1975. Les sols d'un massif de roches ultrabasiques de Nouvelle-Caledonie: le Boulinda. Les sols à accumulation ferrugineuse. Cahiers ORSTOM, Série Pédologie 13, pp. $159-172$.

Lee, B.D., Sears, S.K., Graham, R.C., Amrhein, C., Vali, H., 2003. Secondary mineral genesis from chlorite and serpentine in an ultramafic soil toposequence. Soil Science Society of America Journal 67(4), pp. 1309-1317.

Lewis, J.F., Draper, G., Espaillat, J., Proenza, J.A., Jiménez, J., 2006. Ophiolite-related ultramafic rocks (serpentinites) in the Caribbean region: A review of their occurrence, composition, origin, emplacement and Ni-laterite soil formation. Geologica Acta 4(1), pp. 237-264.

Leleyter, L., Probst, J.L., 1999. A new sequential extraction procedure for the speciation of particulate trace elements in river sediments. International Journal of Environmental Analytical Chemistry 73, pp. 109-128.

L'Huillier, L., Edighoffer, S., 1996. Extractability of nickel and its concentration in cultivated plants in Ni-rich ultramafic soils of New Caledonia. Plant and Soil 186(2), 255-264. 
Lindsay, W.L., Norvell, W.A., 1978. Development of DTPA soil test for zinc, iron, manganese, and copper. Soil Science Society of America Journal 42, pp. 421-428

Lucero, D.W., Martens, D.C., McKenna, J.R., Starner, D.E., 1998. Comparison of Mehlich 3and Bray 1-extractable phosphorus levels in a Starr clay loam amended with poultry litter. Communications in Soil Science and Plant Analysis 29(9-10), pp. 1133-1142.

Madden, M.S., 1988. Adapting the $\operatorname{Sr}\left(\mathrm{NO}_{3}\right)_{2}$ method for determining available cations to a routine soil testing procedure. M.Sc. thesis, University of Wisconsin, Madison.

Massoura, S. T., Echevarria, G., Leclerc-Cessac, E., Morel, J. L., 2004. Response of excluder, indicator and hyperaccumulator plants to nickel availability in soils. Australian Journal of Soil Research 42(8), pp. 933-938.

Massoura, S.T., Echevarria, G., Becquer, T., Ghanbaja, J., Leclerc-Cessac, E., Morel, J.L., 2006. Control of nickel availability by nickel bearing minerals in natural and anthropogenic soils. Geoderma 136(1-2), pp. 28-37.

McLaughlin, M.J., Zarcinas, B.A., Stevens, D.P., Cook, N., 2000. Soil testing for heavy metals. Communications in Soil Science and Plant Analysis 31(11-14), pp. 1661-1700.

Meers, E., Samson, R., Tack, F.M.G., Ruttens, A., Vandegehuchte, M., Vangronsveld, J., Verloo, M.G., 2007. Phytoavailability assessment of heavy metals in soils by single extractions and accumulation by Phaseolus vulgaris. Environmental and Experimental Botany, 60(3), pp. 385-396.

Mehlich, A., 1984. Mehlich-3 soil test extractant: a modification of Mehlich-2 extractant. Communications in Soil Science and Plant Analysis 15(12), pp. 1409-1416.

Mengel, K., Kirkby, E.A., 2001. Principles of Plant Nutrition. Springer (2001).

Menzies, N.W., Donn, M.J., Kopittke, P.M., 2007. Evaluation of extractants for estimation of the phytoavailable trace metals in soils. Environmental Pollution, 145(1), pp. 121-130. 
Nagy, L., Proctor, J., 1997. Soil $\mathrm{Mg}$ and $\mathrm{Ni}$ as causal factors of plant occurrence and distribution at the Meikle Kilrannoch ultramafic site in Scotland. New Phytologist 135(3), pp. $561-566$.

Nkrumah, P.N., Baker, A.J.M., Chaney, R.L., Erskine, P.D., Echevarria, G., Morel, J.L., van der Ent, A., 2016. Current status and challenges in developing nickel phytomining: an agronomic perspective. Plant and Soil 406, pp. 55-69.

Novozamsky, I., Lexmond, T.M., Houba, V.J.G., 1993. A single extraction procedure of soil for evaluation of uptake of some heavy metals by plants. International Journal of Environmental Analytical Chemistry 51(1), pp. 47-58.

Oze, C., Fendorf, S., Bird, D.K., Coleman, R.G., 2004. Chromium geochemistry in serpentinized ultramafic rocks and serpentine soils from the Franciscan complex of California. American Journal of Science, 304(1), pp. 67-101.

Pleysier, J.L., Juo, A., 1980. A single-extraction method using silver-thiourea for measuring exchangeable cations and effective CEC in soils with variable charges. Soil Science, 129(4), pp. 205-211.

Proctor, J., Baker, A.J.M., van Balgooy, M., Bruijnzeel, L., Jones, S., Madulid, D., 2000. Mount Bloomfield, Palawan, Philippines: forests on greywacke and serpentinized peridotite. Edinburgh Journal of Botany, 57(01), pp. 121-139.

Proctor, J., Johnston, W.R., Cottam, D.A., Wilson, A.B., 1981. Field-capacity water extracts from serpentine soils. Nature 294:245-246.

Proctor, J., 2003. Vegetation and soil and plant chemistry on ultramafic rocks in the tropical Far East. Perspectives in Plant Ecology Evolution and Systematics, 6(1-2), pp. 105-124.

Quantin, C., Becquer, T., Rouiller, J.H., Berthelin J., 2002. Redistribution of metals in a New Caledonia Ferralsol after microbial weathering. Soil Science Society of America Journal, 66(6), pp. 1797-1804. 
Quantin, C., Ettler, V., Garnier, J., Šebek, O., 2008. Sources and extractibility of chromium and nickel in soil profiles developed on Czech serpentinites. Comptes Rendus Geoscience 340(12), pp. 872-882.

Quevauviller, P., Rauret, G., Muntau, H., 1994. Evaluation of a sequential extraction procedure for the determination of extractable trace metal contents in sediments. Fresenius' Journal of Analytical Chemistry 349, pp. 808-814.

Raous, S., Echevarria, G., Sterckeman, T., Hanna, K., Thomas, F., Martins, E.S., Becquer, T., 2013. Potentially toxic metals in ultramafic mining materials: identification of the main bearing and reactive phases. Geoderma 192, pp. 111-119.

Rayment, G.E., Higginson F.R., 1992. Australian Laboratory Handbook of Soil and Water Chemical Methods. Inkata Press, Melbourne.

Robinson, B.H., Brooks, R.R., Gregg, P.E.H., Kirkman, J.H., 1999. The nickel phytoextraction potential of some ultramafic soils as determined by sequential extraction. Geoderma 87, pp. 293-304.

Robinson, B., Fernandez, J., Madejon, P., Maranon, T., Murillo, J., Green, S., Clothier, B., 2003. Phytoextraction: an assessment of biogeochemical and economic viability. Plant and Soil 249(1), pp. 117-125.

Searle, P.L., 1986. The measurement of soil cation exchange properties using the single extraction, silver thiourea method-an evaluation using a range of New Zealand soils. Soil Research 24(2), pp. 193-200.

Römkens, P.F., Guo, H.-Y., Chu, C.-L., Liu, T.-S., Chiang, C.-F., Koopmans, G.F., 2009. Characterization of soil heavy metal pools in paddy fields in Taiwan: chemical extraction and solid-solution partitioning. Journal of Soils and Sediments 9(3), pp. 216-228.

Sharpley, A.N., Kleinman, P.J., Weld, J.L., 2008. Environmental soil phosphorus indices. In: Carter, M.R., Gregorich, E.G., editors. Soil Sampling and Methods of Analysis, 2nd Edition. Canadian Society of Soil Science. CRC Press, Boca Raton, FL, pp. 141-159. 
Siebecker, M., Sparks D.L., 2010. Nickel speciation in serpentine soils using synchrotron radiation techniques. 2010 19th World Congress of Soil Science, Soil Solutions for a Changing World. 1 - 6 August 2010, Brisbane, Australia.

Siebielec, G., Chaney, R.L., Kukier, U., 2007. Liming to remediate Ni contaminated soils with diverse properties and a wide range of Ni concentration. Plant and Soil, 299(1-2), pp. $117-130$.

Sukkariyah, B.F., Evanylo, G., Zelazny, L., Chaney, R.L., 2005. Cadmium, copper, nickel, and zinc availability in a biosolids-amended piedmont soil years after application. Journal of Environmental Quality 34, pp. 2255-2262.

Tiller, K.G., Gehrt, J., Bruemmer, G., 1984. The sorption of Cd, Zn and Ni by soil clay fractions: Procedures for partition of bound forms and their interpretation. Geoderma 34, pp. $1-16$.

Ünver, İ., Madenoğlu, S., Dilsiz, A., Namlı, A., 2013. Influence of rainfall and temperature on DTPA extractable nickel content of serpentine soils in Turkey. Geoderma 202-203(C), pp. 203-211.

Van der Ent, A., Baker, A.J.M., Reeves, R.D., Pollard, A.J., Schat, H., 2013a. Hyperaccumulators of metal and metalloid trace elements: Facts and fiction. Plant and Soil 362(1-2), pp. 1-16.

Van der Ent, A., Baker, A.J.M., van Balgooy, M.M.J., Tjoa, A. 2013b. Ultramafic nickel laterites in Indonesia (Sulawesi, Halmahera): mining, nickel hyperaccumulators and opportunities for phytomining. Journal of Geochemical Exploration 128: 72-79.

Van der Ent, A., Erskine, P.D., Sumail S., 2015a. Ecology of nickel hyperaccumulator plants from ultramafic soils in Sabah (Malaysia). Chemoecology, 25(5), pp. 243-259.

Van der Ent, A., Sumail, S., Clarke, C., 2015b. Habitat differentiation of obligate ultramafic Nepenthes endemic to Mount Kinabalu and Mount Tambuyukon (Sabah, Malaysia). Plant Ecology 216, pp. 789-807. 
Van der Ent, A., Baker, A.J.M., Reeves, R.D., Chaney, R.L., Anderson, C.W.N., Meech, J.A., Erskine, P.D., Simonnot, M-O., Vaughan, J., Morel, J.L., Echevarria, G., Fogliani, B., Rongliang, Q., Mulligan, D.R., 2015c. Agromining: farming for metals in the future? Environmental Science and Technology 49, pp. 4773-4780.

Van der Ent, A., Erskine, P.D., Mulligan, D.R., Repin, R., Karim, R., 2016a. Vegetation on ultramafic edaphic islands in Kinabalu Park (Sabah, Malaysia) in relation to soil chemistry and altitude. Plant and Soil, 403(1), pp. 77-101.

Van der Ent, A., Echevarria, G., Tibbett, M., 2016b. Delimiting soil chemistry thresholds for nickel hyperaccumulator plants in Sabah (Malaysia). Chemoecology 26(2), pp. 67-82.

Van der Ent, A., Cardace, D., Tibbett, M., Echevarria, G., 2018. Ecological implications of pedogenesis and geochemistry of ultramafic soils in Kinabalu Park (Malaysia). Catena 160, pp. 154-169.

Vlamis, J., Jenny, H., 1948. Calcium deficiency in serpentine soils as revealed by absorbent technique. Science 107, pp. 549.

Walker, R.B., 1954. The ecology of serpentine soils. II. Factors affecting plant growth on serpentine soils. Ecology 35, pp. 259-266.

Walker, R.B., Walker, H.M., Ashworth, P.R., 1955. Calcium-magnesium nutrition with special reference to serpentine soils. Plant Physiology 30(3), pp. 214-221.

Wang, W.-S., Shan, X.-Q., Wen, B., Zhang, S.-Z., 2003. Relationship between the extractable metals from soils and metals taken up by maize roots and shoots. Chemosphere 53(5), pp. 523-530. 


\section{TABLES}

Table 1. Chemical soil extractants used in this study.

Table 2. Selective sequential extraction scheme.

Table 3. Elemental concentrations (ranges and means) in different extracts $\left(\mu \mathrm{g} \mathrm{g}^{-1}\right), \mathrm{n}=343$.

Table 4. Multivariate regression analysis of Ni-extractions and multivariate regression analysis of Co-extractions.

Table 5. Correlations of extractability of different elements in extracts (major cations), $\mathrm{n}=$ $343 * *$ denotes $\mathrm{p}<0.0001$.

Table 6. Sequential and non-sequential extraction of a) Ni, b) $\mathrm{Co}$, c) $\mathrm{Cr}$ and d) $\mathrm{Mn}$ in 14 representative soils (as percentage of AR digest). The $\mathrm{pH}$ of the representative soils ranges from 5.11 to 9.19. Sequential extraction: exchangeable (Exch.), oxidisable Mn-oxides (Mn$\mathrm{OX}$ ), amorphous Fe-oxides (AM-Fe) or crystalline Fe-oxides (CR-FE); non-sequential extraction: carboxylic acid (Carbox.), 0.1 M strontium nitrate $\left.\left(\mathrm{SrNO}_{3}\right)_{2}\right)$ or Melhich-3 (ML3); and digest: digest with either $\mathrm{HNO}_{3}+\mathrm{HCl}(\mathrm{AR})$ or $\mathrm{HNO}_{3}+\mathrm{HCl}+\mathrm{HF}(\mathrm{HF})$. <LOD denotes below detection limit. 


\section{FIGURES}

Figure 1. Boxplots of $\mathrm{Ni}, \mathrm{Co}, \mathrm{Cr}, \mathrm{Mn}$ in various soil extracts $\left(\mu \mathrm{g} \mathrm{g}^{-1}\right)$. Key to symbols: open squares are the \pm mean, whiskers are \pm standard deviation, circles are outliers and asterisks are extreme outliers.

Figure 2. Plot of principal component analysis (PCA) of a) Ni extractability in DTPA, 0.1 M $\mathrm{CaCl}_{2}, 0.1 \mathrm{M} \mathrm{Sr}\left(\mathrm{NO}_{3}\right)_{2}$ and Mehlich-3 extracts and b) Co extractability in DTPA, $0.1 \mathrm{M}$ $\mathrm{CaCl}_{2}, 0.1 \mathrm{M} \mathrm{Sr}\left(\mathrm{NO}_{3}\right)_{2}$ and Mehlich-3 extracts.

Figure 3. Principal component analysis of nickel extractability in extracts of $0.1 \mathrm{M} \mathrm{Sr}\left(\mathrm{NO}_{3}\right)_{2}$, $0.01 \mathrm{M}$ and $0.1 \mathrm{M} \mathrm{CaCl}_{2}$ ), versus extraction solution $\mathrm{pH}$.

Figure 4. Principal component analysis of extractable K in AgTU, carboxylic acid (CA), $\mathrm{Sr}\left(\mathrm{NO}_{3}\right)_{2}(0.1 \mathrm{M})$ and Mehlich-3 extracts. 
TABLE 1

\begin{tabular}{|c|c|c|c|}
\hline Extraction medium & Liquid:soil ratio & Equilibrium time & References \\
\hline \multicolumn{4}{|c|}{ Neutral-salt extracts } \\
\hline $0.1 \mathrm{M}$ Strontium nitrate & $4: 1$ & $1 \mathrm{hr}$ & Wang et al., 2003 \\
\hline $0.01 \mathrm{M}$ Strontium nitrate & $4: 1$ & $1 \mathrm{hr}$ & Kukier et al., 2004 \\
\hline $0.1 \mathrm{M}$ Calcium chloride & $4: 1$ & $1 \mathrm{hr}$ & Meers et al., 2011 \\
\hline $0.01 \mathrm{M}$ Calcium chloride & $4: 1$ & $1 \mathrm{hr}$ & Meers et al., 2011 \\
\hline \multicolumn{4}{|c|}{ Chelator extracts } \\
\hline DTPA-TEA pH 7.4 & $5: 1$ & $2 \mathrm{hrs}$ & Lindsay and Norvell, 1978 \\
\hline DTPA pH 5.3 & $5: 1$ & $2 \mathrm{hrs}$ & Becquer et al., 1995 \\
\hline \multicolumn{4}{|c|}{ Acid based extracts } \\
\hline $\begin{array}{c}\text { 70\% Nitric acid, } 37 \% \\
\text { hydrochloric acid }\end{array}$ & $12: 0.3$ & $1 \mathrm{hr}$ & $\begin{array}{c}\text { Rayment and Higginson, } \\
1992\end{array}$ \\
\hline $\begin{array}{l}\text { Carboxylic acid mix } \\
\text { (Acetic, malic, citric } \\
\text { acid) }\end{array}$ & & $2 \mathrm{hrs}$ & Feng et al., 2005 \\
\hline \multicolumn{4}{|c|}{ Exchangeable cations } \\
\hline $1 \mathrm{M}$ ammonium acetate & $10: 1$ & $2 \mathrm{hrs}$ & DIN, 1995 \\
\hline $0.01 \mathrm{M}$ Silverthiorea & 40:0.8 & $16 \mathrm{hrs}$ & Pleysier and Juo, 1980 \\
\hline \multicolumn{4}{|c|}{ Phosphorus extracts } \\
\hline $\begin{array}{l}\text { Olsen-P (sodium hydrogen } \\
\text { carbonate) }\end{array}$ & 20:1 & $30 \mathrm{~min}$. & Olsen et al., 1954 \\
\hline $\begin{array}{l}\text { Mehlich-3 (ammonium } \\
\text { fluoride based) }\end{array}$ & 10:1 & 5 min. & Mehlich, 1985 \\
\hline
\end{tabular}




\section{TABLE 2}

\begin{tabular}{|c|c|c|}
\hline Fraction & Reagents & Conditions \\
\hline Water soluble and exchangeable & $0.01 \mathrm{M} \mathrm{Sr}\left(\mathrm{NO}_{3}\right)_{2}$ & 2 hours at $20^{\circ} \mathrm{C}$ \\
\hline Bound to Mn-oxides & 0.1 M hydroxylammonium chlor & 30 minute at $20^{\circ} \mathrm{C}$ \\
\hline Bound to amorphous Fe-oxides & $0.2 \mathrm{M}$ ammonium oxalate $+0.2 \mathrm{M}$ oxalic acid & 4 hours in the dark at $20^{\circ} \mathrm{C}$ \\
\hline Bound to crystalline Fe-oxides & $0.2 \mathrm{M}$ ammonium oxalate $+0.2 \mathrm{M}$ oxalic acid $+0.1 \mathrm{M}$ ascorbic acid & 30 minutes at $90^{\circ} \mathrm{C}$ in water bath \\
\hline Residual & $70 \% \mathrm{HNO}_{3}+32 \% \mathrm{HCl}+37 \% \mathrm{HF}$ & 1 hour at $115^{\circ} \mathrm{C}$ in digestion microwave \\
\hline
\end{tabular}


TABLE 3

\begin{tabular}{|c|c|c|c|c|c|c|c|c|c|c|}
\hline \multirow[b]{2}{*}{ Al } & \multicolumn{2}{|c|}{ DTPA extract $\mu \mathrm{g} \mathrm{g}^{-1}$} & \multicolumn{2}{|c|}{ Mehlich-3 extract $\mu \mathrm{g} \mathrm{g}^{-1}$} & \multicolumn{2}{|c|}{$\mathrm{Sr}\left(\mathrm{NO}_{3}\right)_{2}$ extract $\mu \mathrm{g} \mathrm{g}^{-1}$} & \multicolumn{2}{|c|}{ Carboxylic extract $\mu \mathrm{g} \mathrm{g}^{-1}$} & \multicolumn{2}{|c|}{$\mathrm{HNO}_{3} / \mathrm{HCl}$ digest $\mu \mathrm{g} \mathrm{g}^{-1}$} \\
\hline & $0.3-485$ & 55 & $17-1750$ & 415 & $0.1-220$ & 15 & $5.8-4250$ & 265 & $1200-118000$ & 19600 \\
\hline $\mathbf{C a}$ & - & - & $3.1-2600$ & 230 & $1.8-1770$ & 210 & $2.1-1550$ & 125 & $205-24500$ & 2100 \\
\hline Co & $0.1-95$ & 20 & $0.5-70$ & 15 & $0.1-25$ & 1.8 & $0.2-275$ & 40 & $0.5-1500$ & 250 \\
\hline $\mathrm{Cr}$ & $0.1-15$ & 0.5 & $0.04-40$ & 2.5 & $0.1-25$ & 0.3 & $0.3-85$ & 5.8 & $225-21800$ & 4000 \\
\hline $\mathbf{C u}$ & $0.1-25$ & 1.5 & $0.3-125$ & 5.0 & $0.1-25$ & 0.2 & $0.1-8.7$ & 0.5 & $2.5-325$ & 50 \\
\hline $\mathbf{F e}$ & $0.6-875$ & 95 & $25-1750$ & 210 & $0.1-35$ & 1.1 & $12.1-2350$ & 410 & $21500-535000$ & 157000 \\
\hline $\mathbf{K}$ & $1.0-110$ & 30 & $<0.01-440$ & 35 & $0.1-135$ & 30 & $0.1-95$ & 25 & $0.1-1060$ & 90 \\
\hline Mg & $2.9-1100$ & 315 & $5.1-6850$ & 980 & $5.0-3150$ & 510 & $4.0-7850$ & 620 & 270-235000 & 26700 \\
\hline Mn & $0.4-780$ & 190 & $0.7-1150$ & 215 & $0.3-11800$ & 445 & $0.4-3700$ & 550 & $45-33500$ & 3250 \\
\hline $\mathrm{Na}$ & $1.9-25$ & 10 & $6.6-345$ & 25 & $0.5-30$ & 7.1 & $0.1-65$ & 5.8 & $0.1-360$ & 105 \\
\hline $\mathbf{N i}$ & $0.2-275$ & 50 & $0.4-620$ & 55 & $0.1-65$ & 7.9 & $0.2-405$ & 55 & $15-7000$ & 1440 \\
\hline $\mathbf{P}$ & $0.1-15$ & 0.7 & $<0.01-30$ & 2.0 & $0.1-735$ & 60 & $0.1-45$ & 1.6 & $20-485$ & 130 \\
\hline $\mathbf{S}$ & $1.0-215$ & 17 & $<0.01-115$ & 16.5 & $0.1-20$ & 1.2 & $0.8-80$ & 9.6 & $85-755$ & 350 \\
\hline $\mathbf{Z n}$ & $0.1-4.8$ & 0.7 & $0.1-5.0$ & 1.0 & $0.1-15$ & 3.0 & $0.1-3.1$ & 0.8 & $15-375$ & 115 \\
\hline
\end{tabular}


TABLE 4

\begin{tabular}{|c|c|c|c|c|}
\hline Extraction method & $\boldsymbol{\delta}$ & $\alpha$ & $\beta$ & $\gamma$ \\
\hline Carboxylic acid Ni & -3.45 & 0.70 & 0.40 & 0.30 \\
\hline DTPA Ni & -2.50 & 0.85 & 0.10 & 0.50 \\
\hline $0.1 \mathrm{M} \mathrm{Sr}\left(\mathrm{NO}_{3}\right)_{2} \mathrm{Ni}$ & -0.90 & 0.70 & -0.25 & 0.45 \\
\hline Mehlich-3 Ni & -2.80 & 0.65 & 0.30 & 0.40 \\
\hline Carboxylic acid Co & -0.85 & 0.95 & -0.07 & 0.19 \\
\hline DTPA Co & -0.025 & 0.90 & -0.25 & 0.20 \\
\hline $0.1 \mathrm{M} \mathrm{Sr}\left(\mathrm{NO}_{3}\right)_{2} \mathrm{Co}$ & 0.80 & 0.70 & -0.45 & 0.05 \\
\hline Mehlich-3 Co & -0.40 & 0.65 & -0.05 & 0.15 \\
\hline
\end{tabular}


TABLE 5

\begin{tabular}{|c|c|c|c|c|c|}
\hline & $\mathrm{HNO}_{3} / \mathrm{HCl}$ & $\mathrm{Sr}\left(\mathrm{NO}_{3}\right)_{2}$ & $\begin{array}{l}\text { carboxylic } \\
\text { acid }\end{array}$ & Mehlich-3 & DTPA \\
\hline \multicolumn{6}{|c|}{$\mathbf{N a}$} \\
\hline $\mathrm{Sr}\left(\mathrm{NO}_{3}\right)_{2}$ & -0.07 & & & & \\
\hline carboxylic acid & -0.08 & $0.90^{* * *}$ & & & \\
\hline Mehlich-3 & 0.10 & $0.30 * *$ & $0.35^{* *}$ & & \\
\hline DTPA & -0.10 & $0.90 * *$ & $0.95^{* *}$ & $0.30 * *$ & \\
\hline silverthiorea & 0.15 & $0.25 * *$ & $0.25 * *$ & -0.10 & $0.25^{* *}$ \\
\hline \multicolumn{6}{|c|}{$\mathrm{Mg}$} \\
\hline $\mathrm{Sr}\left(\mathrm{NO}_{3}\right)_{2}$ & $0.50 * *$ & & & & \\
\hline carboxylic acid & $0.70^{* * *}$ & $0.55^{* *}$ & 12 & & \\
\hline Mehlich-3 & $0.70 * *$ & $0.80 * *$ & $0.80^{* *}$ & & \\
\hline DTPA & $0.60^{* * *}$ & $0.85^{* *}$ & $0.65^{* *}$ & $0.90^{* *}$ & \\
\hline silverthiorea & $0.40 * *$ & $0.50 * *$ & $0.65 * *$ & $0.60 * *$ & $0.60 * *$ \\
\hline \multicolumn{6}{|c|}{ K } \\
\hline $\mathrm{Sr}\left(\mathrm{NO}_{3}\right)_{2}$ & 0.20 & 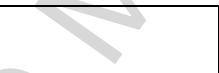 & & & \\
\hline carboxylic acid & $0.25^{* *}$ & $0.90 * *$ & & & \\
\hline Mehlich-3 & $0.25 * *$ & $0.75^{* *}$ & $0.80 * *$ & & \\
\hline DTPA & $0.25 * *$ & $0.90 * *$ & $0.95^{* *}$ & $0.75^{* *}$ & \\
\hline silverthiorea & $0.30 * *$ & $0.85 * *$ & $0.90 * *$ & $0.75^{* *}$ & $0.90 * *$ \\
\hline \multicolumn{6}{|c|}{ Al } \\
\hline $\mathrm{Sr}\left(\mathrm{NO}_{3}\right)_{2}$ & $0.50 * *$ & & & & \\
\hline carboxylic acid & $0.70 * *$ & $0.50 * *$ & & & \\
\hline Mehlich-3 & $0.70 * *$ & $0.55 * *$ & $0.9^{* * *}$ & & \\
\hline DTPA & $0.50 * *$ & $0.50 * *$ & $0.70^{* *}$ & $0.80 * *$ & \\
\hline silverthiorea & $0.50^{* *}$ & $0.55^{* *}$ & $0.65^{* *}$ & $0.65^{* *}$ & $0.75^{* *}$ \\
\hline \multicolumn{6}{|c|}{$\mathrm{Ca}$} \\
\hline $\mathrm{Sr}\left(\mathrm{NO}_{3}\right)_{2}$ & $0.55^{* *}$ & & & & \\
\hline carboxylic acid & $0.55 * *$ & $0.85^{* *}$ & & & \\
\hline Mehlich-3 & $0.55^{* * *}$ & $0.85^{* *}$ & $0.95^{* *}$ & & \\
\hline silverthiorea & $0.55^{* *}$ & $0.85^{* *}$ & $0.95 * *$ & $0.95 * *$ & \\
\hline
\end{tabular}


Table 5-continued.

\begin{tabular}{|c|c|c|c|c|}
\hline & $\mathrm{HNO}_{3} / \mathrm{HCl}$ & $\begin{array}{l}\text { carboxylic } \\
\text { acid }\end{array}$ & $\mathrm{Sr}\left(\mathrm{NO}_{3}\right)_{2}$ & Mehlich-3 \\
\hline \multicolumn{5}{|c|}{ Co } \\
\hline carboxylic acid & $0.80 * *$ & & & \\
\hline $\mathrm{Sr}\left(\mathrm{NO}_{3}\right)_{2}$ & $0.30 * *$ & $0.20 * *$ & H & \\
\hline Mehlich-3 & $0.70 * *$ & $0.75 * *$ & $0.60 * *$ & \\
\hline DTPA & $0.70 * *$ & $0.80 * *$ & $0.55 * *$ & $0.95 * *$ \\
\hline \multicolumn{5}{|c|}{$\mathrm{Cr}$} \\
\hline carboxylic acid & 0.09 & & & \\
\hline $\mathrm{Sr}\left(\mathrm{NO}_{3}\right)_{2}$ & -0.04 & $0.35 * *$ & & \\
\hline Mehlich-3 & -0.10 & 0.00 & -0.05 & \\
\hline DTPA & 0.10 & $0.50 * *$ & $0.80^{* *}$ & -0.05 \\
\hline \multicolumn{5}{|c|}{$\mathrm{Fe}$} \\
\hline carboxylic acid & -0.10 & & & \\
\hline $\mathrm{Sr}\left(\mathrm{NO}_{3}\right)_{2}$ & -0.05 & 0.015 & & \\
\hline Mehlich-3 & $-0.40 * *$ & $0.60 * *$ & $0.25 * *$ & \\
\hline DTPA & -0.10 & $0.25 * *$ & $0.60 * *$ & $0.45^{* *}$ \\
\hline \multicolumn{5}{|c|}{ Mn } \\
\hline carboxylic acid & $0.75^{* * *}$ & & & \\
\hline $\mathrm{Sr}\left(\mathrm{NO}_{3}\right)_{2}$ & 0.05 & 0.05 & & \\
\hline Mehlich-3 & $0.55 * *$ & $0.75^{*}$ & 0.005 & \\
\hline DTPA & $0.55^{* *}$ & $0.75 * *$ & 0.025 & $0.90 * *$ \\
\hline \multicolumn{5}{|c|}{$\mathrm{Ni}$} \\
\hline carboxylic acid & $0.5^{* *}$ & & & \\
\hline $\mathrm{Sr}\left(\mathrm{NO}_{3}\right)_{2}$ & $0.25 * *$ & $0.30 * *$ & & \\
\hline Mehlich-3 & $0.30 * *$ & $0.65 * *$ & $0.40 * *$ & \\
\hline DTPA & $0.50 * *$ & $0.50 * *$ & $0.55^{* *}$ & $0.50 * *$ \\
\hline
\end{tabular}




\section{TABLE 6a}






\section{TABLE $6 \mathrm{~b}$}




TABLE 6c

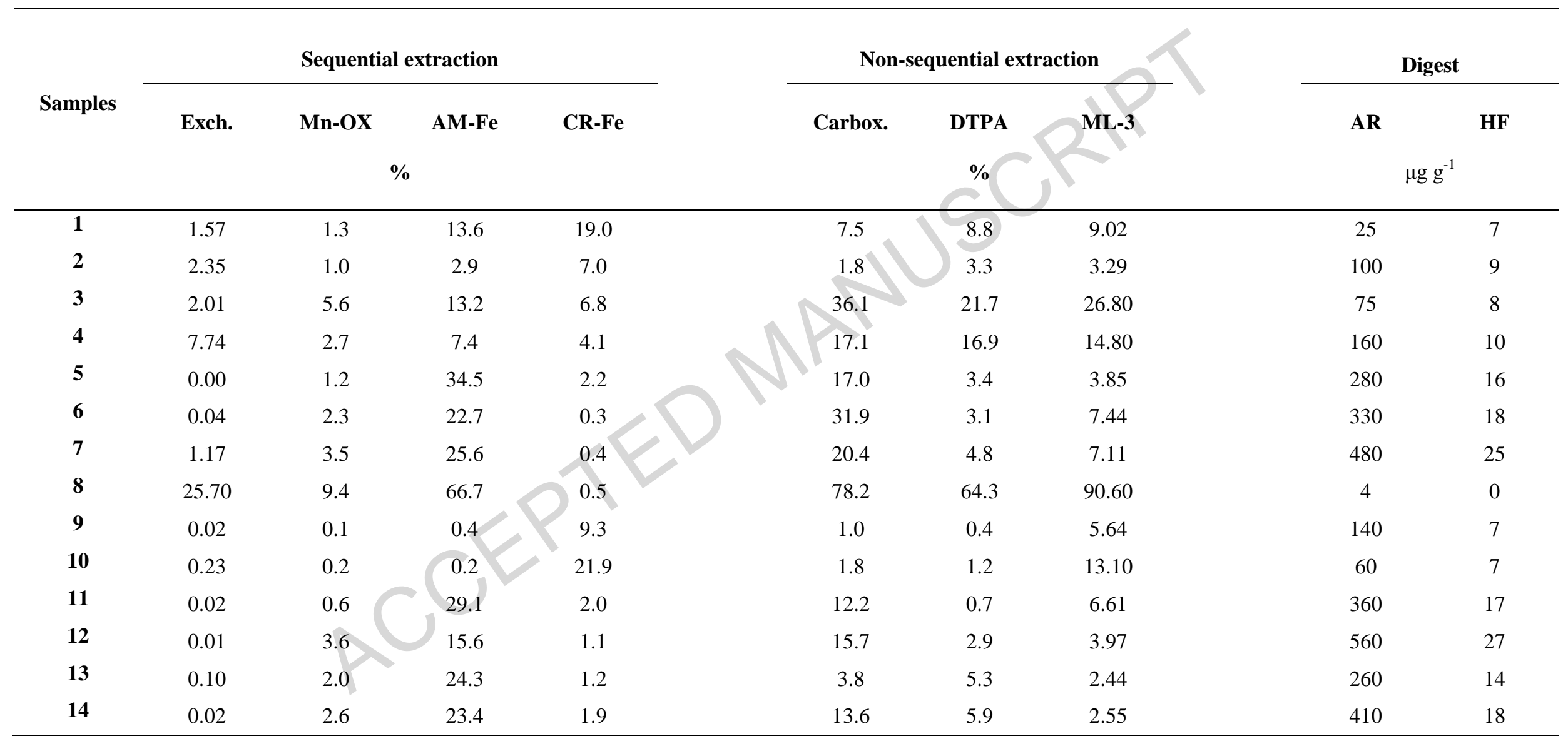




\section{TABLE 6d}

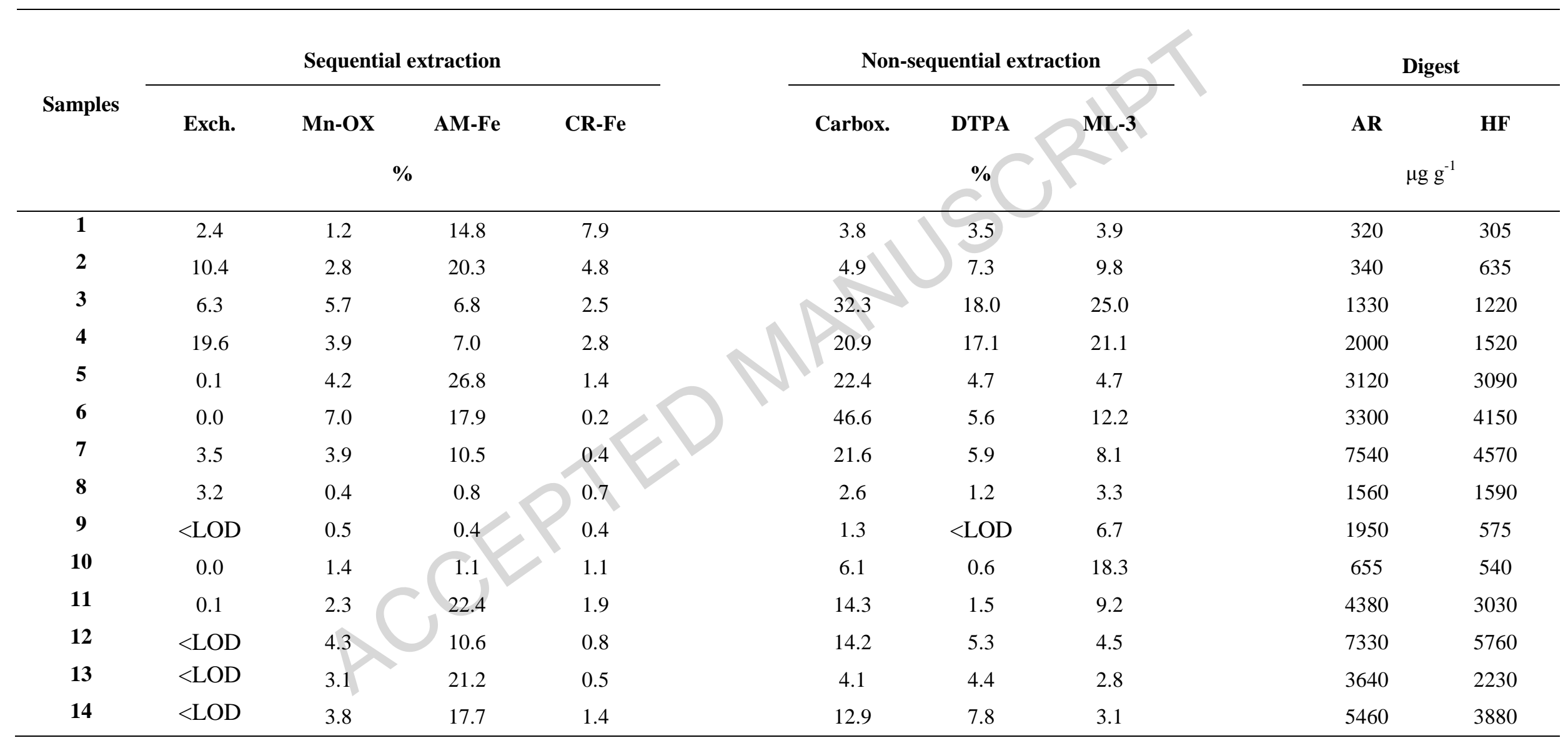




\section{Highlights}

1. Extraction solution $\mathrm{pH}$ affects metal extractability in tropical ultramafic soils.

2. Nickel bearing-phases influence its phytoavailability.

3. The carboxylic acid method is suited for characterizing tropical ultramafic soils.

4. Ecological interpretation remains difficult without plant uptake data. 

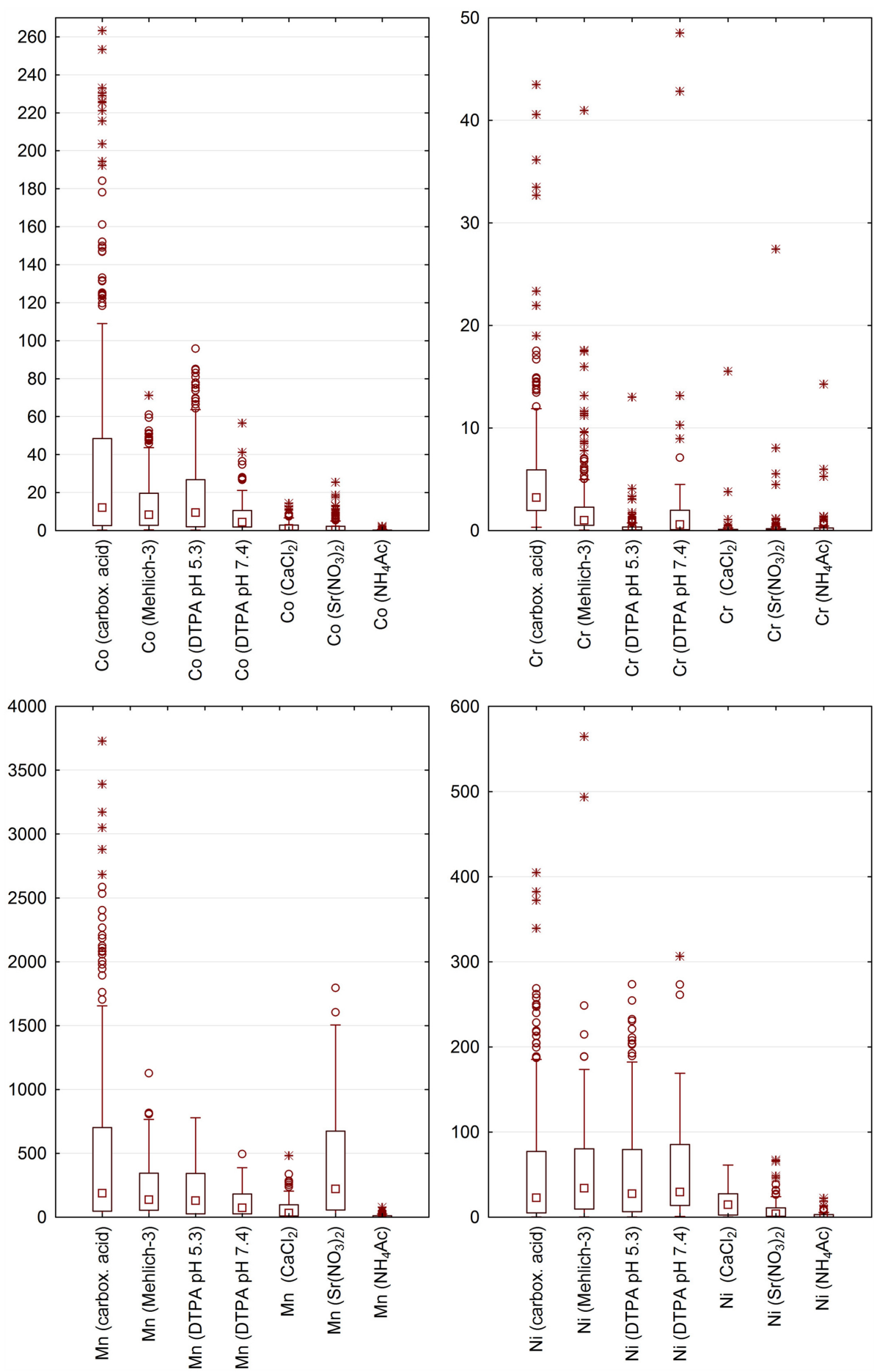

Figure 1 
a)

Projection of the variables on the factor-plane $\left(\begin{array}{ll}1 \times & 2\end{array}\right)$

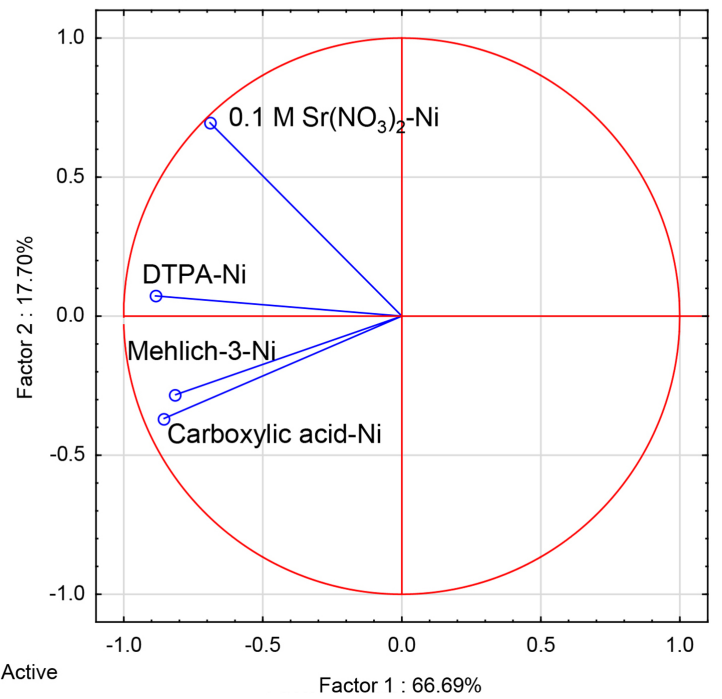

b)

Projection of the variables on the factor-plane $\left(\begin{array}{ll}1 \times & 2\end{array}\right)$

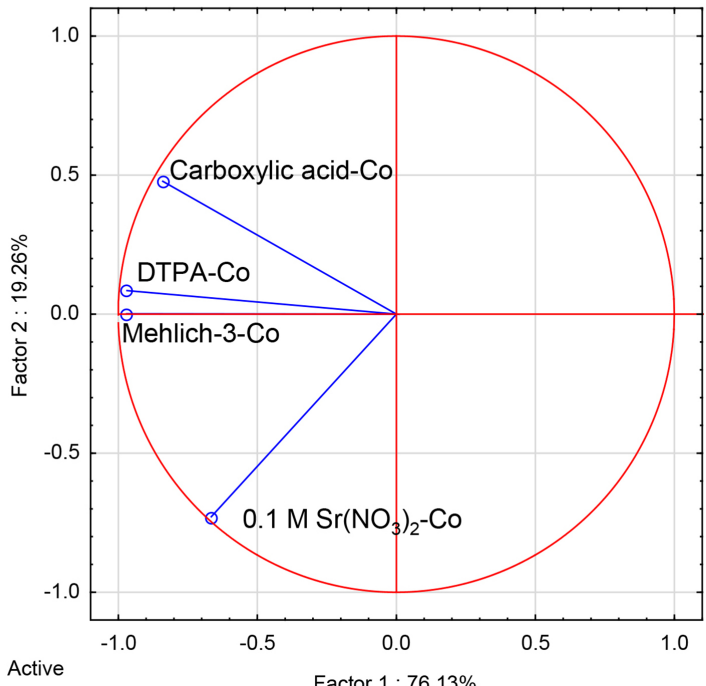

Figure 2 
Projection of the variables on the factor-plane $\left(\begin{array}{ll}1 \times 2 & 2\end{array}\right)$

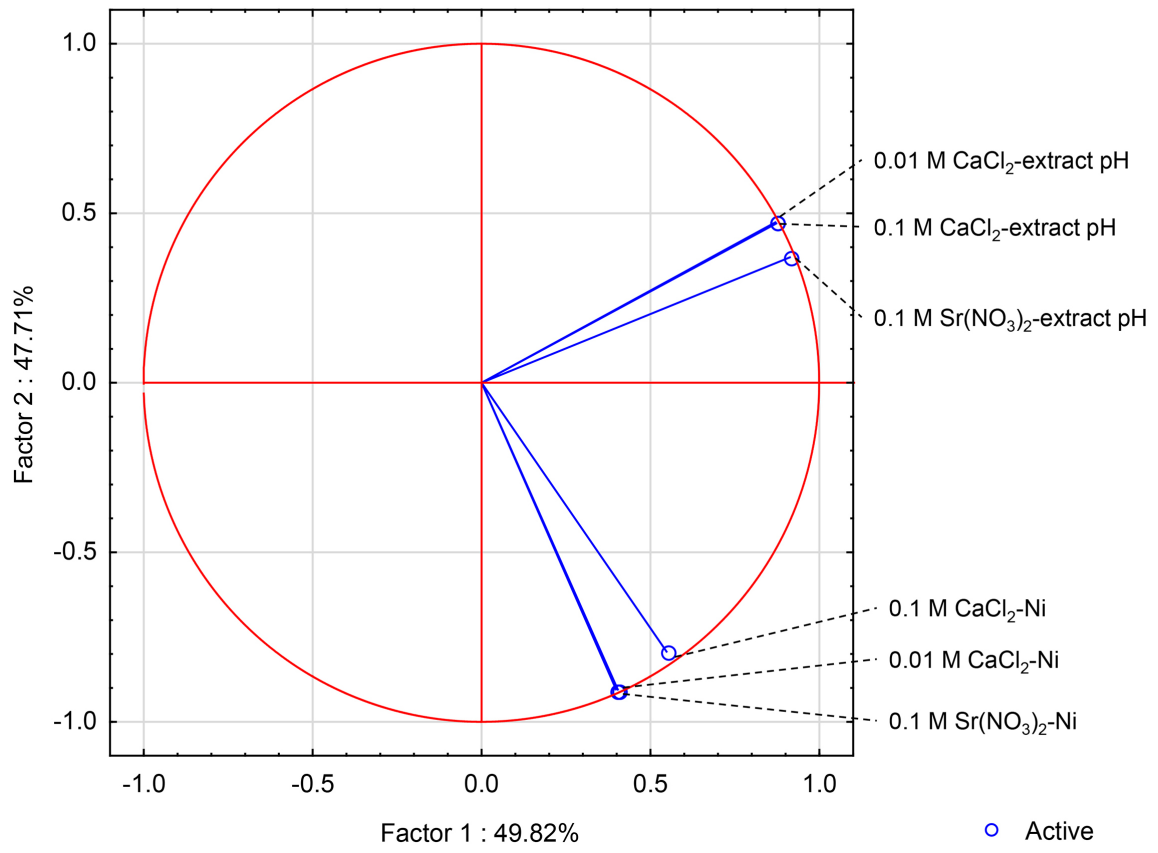

Figure 3 
Projection of the variables on the factor-plane $\left(\begin{array}{ll}1 \times & 2\end{array}\right)$

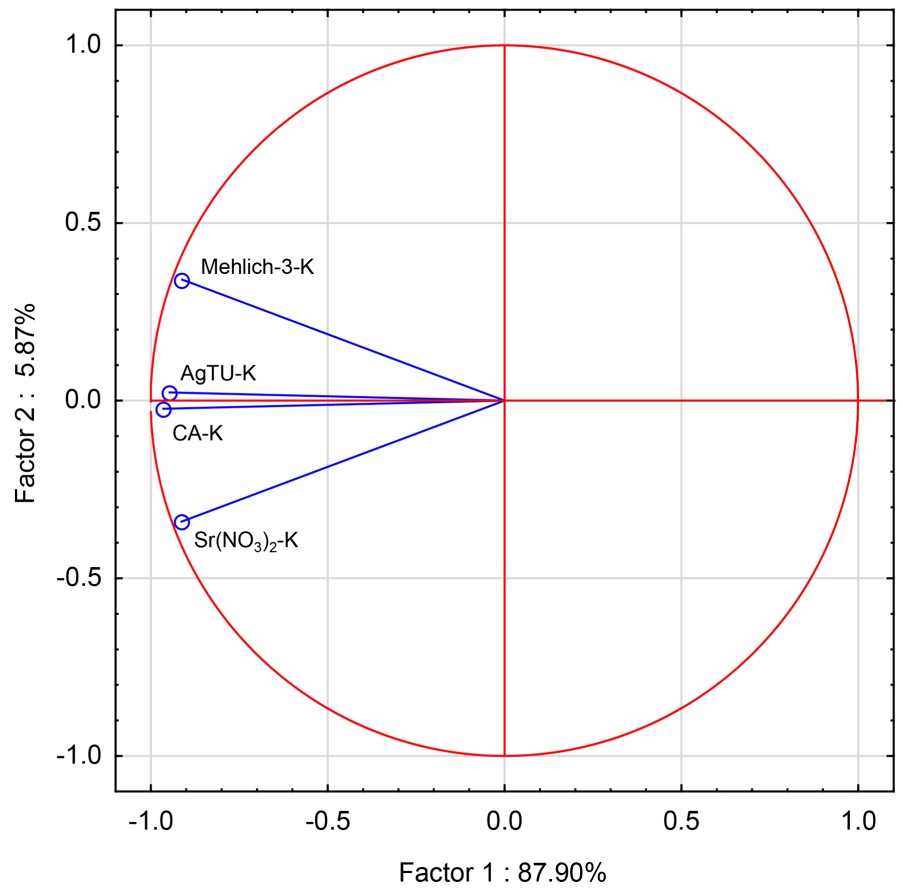

$\circ$ Active

Figure 4 


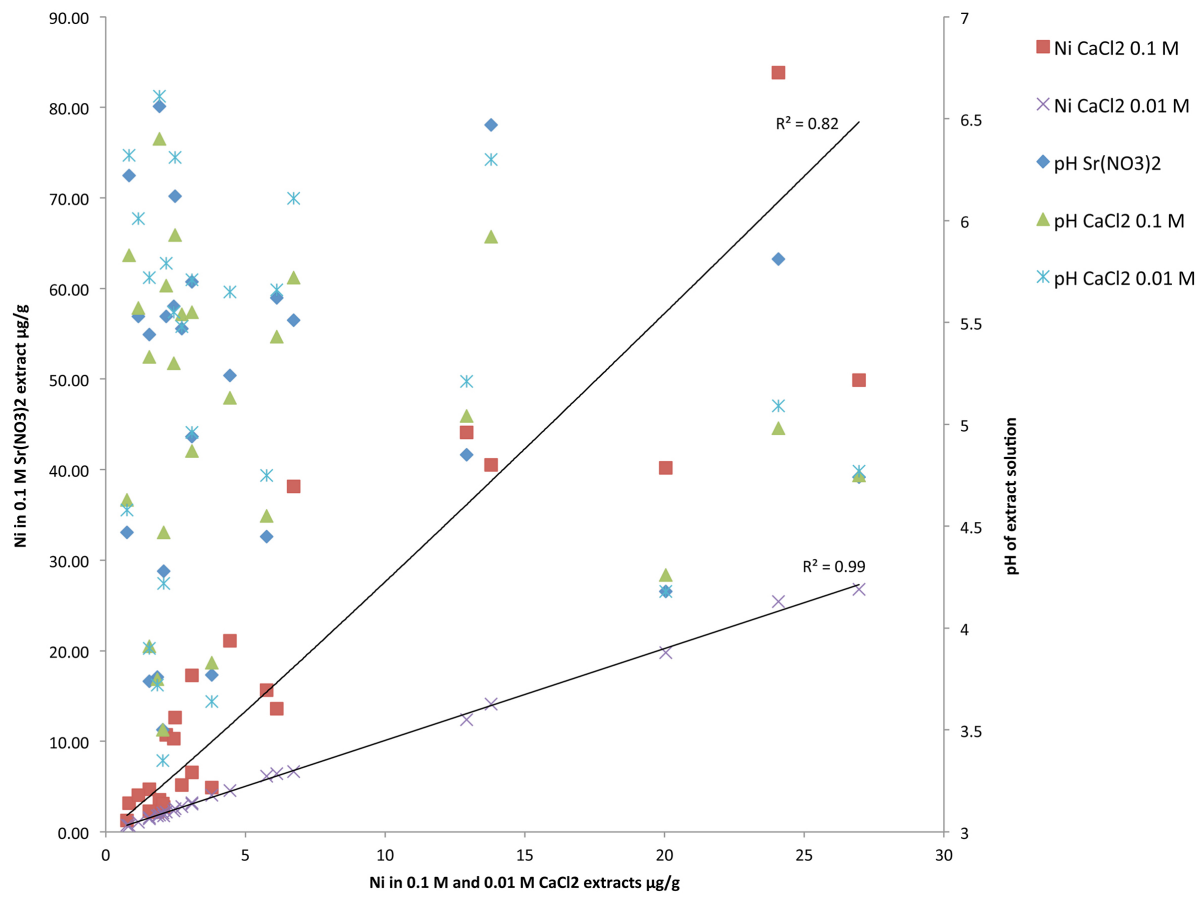

Figure 5 